$\begin{array}{lllllllll}\mathbf{A} & \mathbf{R} & \mathbf{T} & \mathbf{Y} & \mathbf{K} & \mathbf{U} & \mathbf{L} & \mathbf{Y}\end{array}$

Collectanea Theologica

$86(2016) \mathrm{nr} 2$

ARNOLD ZAWADZKI, ŁÓDŹ

\title{
IZRAEL JAKO MESJAŃSKA MĄDROŚĆ I JEJ ŚWIADECTWO POŚRÓD NARODÓW W IZ 55,3-5. STUDIUM EGZEGETYCZO-HISTORYCZNE
}

Perykopa Iz 55,3-5 jest zwieńczeniem Księgi Deuteroizajasza (Iz 40-55) i stanowi sugestywną zapowiedź wiecznego przymierza, które otworzy nowy rozdział w relacji Boga z Izraelem. Czy owa relacja wykroczy poza ramy przymierza synajskiego i Mojżeszowego prawa, wprowadzając zupełnie nową rzeczywistość teologiczną? Czy też będzie kontynuacją starego przymierza $\mathrm{w}$ zmienionej sytuacji społeczno-politycznej? I w j aki sposób to się dokona?

Kiedy w 562 r. przed Chr. po 43 latach długiego panowania umarł Nabuchodonozor II, Babilonia natychmiast weszła w okres dekadencji. Rozsadzana wewnętrznymi sporami, zaczęła tracić na znaczeniu. Jej miejsce, od 550 r. przed Chr., równie szybko zaczęła zajmować młoda i ambitna dynastia perska, która pod rządami Cyrusa II, przy stosunkowo niewielkim nakładzie sił i środków militarnych, powiększała swoje zdobycze. Cyrus poszerzał granice państwa i w trzech ruchach dołączył do niego: państwo Medów (550); Lidię i Cylicję (547); rozległe terytoria aż do doliny Indusu (545-540). ${ }^{1}$ Zwieńczeniem tej błyskawicznej ekspansji terytorialnej było zdobycie w 539 r. przed Chr. Babilonii wraz z podległymi jej ziemiami syro-palestyńskimi. Sławie Cyrusa, niezwyciężonego zdobywcy, towarzyszyły pogłoski o jego wielkoduszności i umiarkowaniu: pobici królowie byli ułaskawiani, zdobyte miasta oszczędzane od zagłady, lokalne sanktuaria i bóstwa otaczane królewską opieką. Cyrus nie zamierzał burzyć klimatu ogólnego pokoju, jaki panował pod rządami Babilończyków.

1 J. A. S o g g i n, Storia d'Israele, Brescia 2002, s. 335-340; L. L. G r a b b e, The Persian and Greek Periods, t. 1, Philadelphia 1992, s. 73-94. 
Wykorzystał go i wprzągł do swojej polityki, czyniąc zeń oręż równie skuteczny jak dwieście lat wcześniej okrutne oddziały Asyryjczyków.

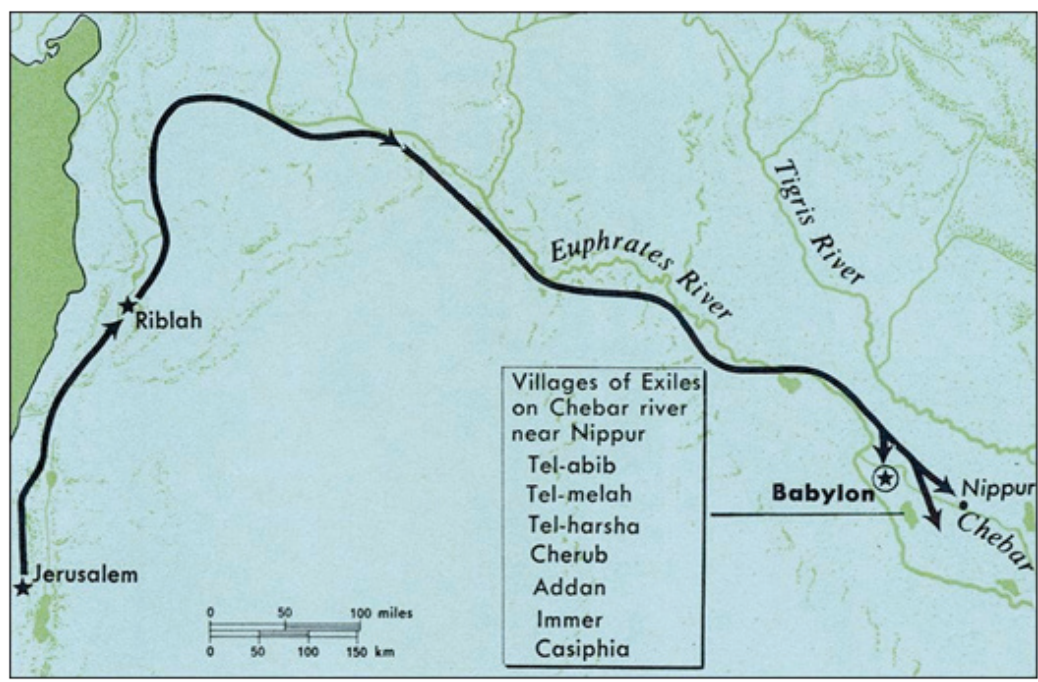

Miejsce osiedlenia się judejskich wygnańców w Babilonii w latach 598-587 przed Chr.

Nagła zmiana na scenie polityki międzynarodowej oddziaływała bezpośrednio na znajdujących się w Babilonii Żydów, którzy podczas pierwszej i drugiej deportacji, w latach 598-587 przed Chr., zamieszkali w regionie miasta Nippur, wzdłuż rzeki Kebar, na dość wąskim obszarze, obejmującym ok. $100 \mathrm{~km}^{2}$. Okoliczne miejscowości były położone, jedna obok drugiej: Tell-Abib, Tel-Melach, Tel-Charsza, Kerub, Addan, Immer i Kasifia (Ez 3,1; Ezd 2,59; 8,17; Ne 7,61). ${ }^{2}$ Geograficzna koncentracja wygnańców sprzyjała zachowaniu ich tożsamości narodowej i religijnej, pielęgnowaniu rodzinnych tradycji

2 „I deportati babilonesi, (...) erano concentrati nella Babilonia in senso stretto (...) nella zona di Nippur, lungo il canale Kebar (...) Erano stanziati soprattutto in cittadine o villaggi abbandonati"; M. L i v e r a n i, Oltre la Bibbia, Bari 2004, s. 238. 
i pamięci przodków. ${ }^{3}$ Jednak lokalizacja nie była jedynym czynnikiem spajającym judejskich wygnańców.

Pośród nich uaktywniła się anonimowa grupa prorocka, nazywana dziś umownie Deuteroizajaszem. ${ }^{4}$ Jej działalność zbiegła się w czasie ze zwycięskim pochodem Cyrusa. Wywodziła ona swe pochodzenie prawdopodobnie spośród kantorów i proroków świątynnych z Jerozolimy, ${ }^{5}$ a jej przesłanie, utrwalone w Iz 40-55, uderzało w nuty nacjonalistyczne i łączyło język psalmów z tradycyjnym językiem prorockim, w którym do dziś wybrzmiewają najważniejsze tematy znane ze Starego Testamentu: stworzenie świata (Iz 40,22b.26.28; 45,6-11), stworzenie człowieka (Iz 43,1; 42,5; 45,12-13; 49,5), prehistoria biblijna (Iz 51,9-10; 54,9), historia patriarchów (Iz 41,8-10; 43,27; 51,1-2), historia Exodusu (Iz 43,16-17; 51,10; 52,12), teologia królewska Dawida (Iz 55,3-5) i teologia świątyni i Syjonu (Iz 40,2.9-11; 41,27; 44,26.28; 45,13; 46,13; 49,14-18; 51,14.16; 52,7-9). Przepowiadanie tej grupy było nie tylko elementem scalającym wygnańców, przypominając im starożytną tradycję, ale również pogłębieniem i aktualizującą refleksją nad własnym losem i tradycją, wprowadzając korektę w rozumienie przymierza synajskiego i otwierając mesjańską wizję przyszłości związaną z postacią sługi Jahwe i nowego Dawida. Konkretnie była to jednak odpowiedź na wewnętrzną frustrację wygnańców i ich religijne rozterki.

Fragmentem skupiającym w sobie istotę owego przesłania jest perykopa Iz 55,1-7, w którym centralną pozycję pełnią ww. 3-5. Jednak tym razem Deuteroizajasz nie kreśli przed Judejczykami wizji triumfalnego pochodu przez pustynię, gdy powrócą na Syjon pod

3 E. J. B i c k e r m a n n, The Babylonian Captivity, w: W. D. D a v i e s, L. F i n k e ls t e in (red.), The Cambridge History of Judaism, Cambridge 1984, t. 1, s. 344-346.

4 D. M i c h e 1, Das Rätsel Deuterojesaja, Theologia Viatorum 13/1975-1976, s. 115-132 widzi w Deuteroizajaszu raczej szkołę prorocką niż indywidualną postać jednego proroka. Jest to pierwsza tego typu hipoteza.

5 C. W e s t e r m a n n, Isaia 40-66, Brescia 1978, s. 17: ,è... del tutto possibile che il Deuteroisaia si trovasse in rapporto con i cantori del tempio, ai quali spettava specialmente la cura della tradizione dei salmi”. 
wodzą Jahwe, ich jedynego Boga dzierżącego berło władzy (Iz 40,9$-11 ; 52,7-12)$, ale zapowiada innego rodzaju przełom.

\section{Analiza egzegetyczno-syntaktyczna Iz 55,3-5}

Egzegeza perykopy Iz 55,3-5 opisuje funkcje syntaktyczne poszczególnych jej członów i pozwala na ukazanie bogactwa znaczeniowego, jakie ten tekst $\mathrm{z}$ sobą niesie zarówno w formie kanonicznej, jak i w niełatwym procesie redakcji.

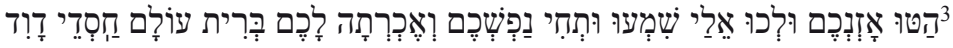

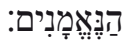

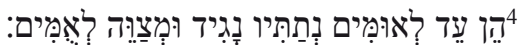

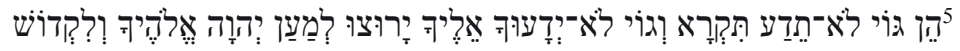

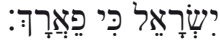

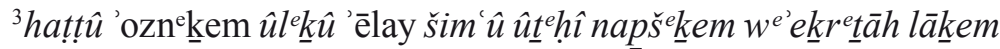
berît 'ôlām has $\underline{\text { de }}$ dāwid hanne' mānîm:

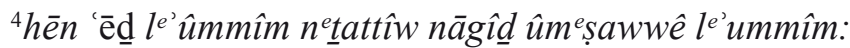

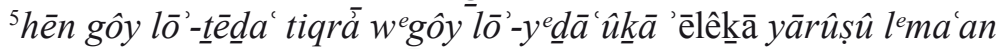

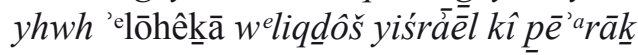

\section{Problem z לִ ְִ (lek $k \underline{u})$ w Iz 55,3a}

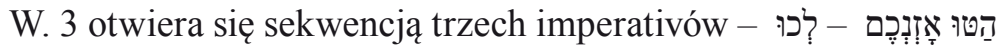

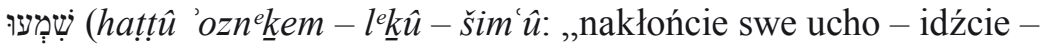
słuchajcie"). Głównym problemem w w. 3a jest znaczenie imperativu לִ (lek $k \hat{u})$ i jego pozycja w logicznym porządku całej wypowiedzi. Wezwanie לִ (lek $k \hat{u}$ - ,idźcie”) powinno stać na początku zdania i poprzedzać zachętę do słuchania. Ponadto forma ל̧ (lek k̂u), pochodząc od czasownika הָָ hālak , oznacza „idźcie”, „pójdźcie”, „ruszcie się”. Nie oznacza „przyjdźcie”, jak proponuje większość nowożytnych tłumaczeń, bo takie tłumaczenie byłoby możliwe tylko

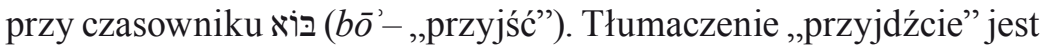
więc niepoprawne i niewłaściwie opisuje relację między podmiotem 
mówiącym i adresatami. Sugeruje bowiem, że podmiot mówiący, znajdując się w pewnym oddaleniu od słuchaczy, zachęca ich do zmniejszenia dystansu czy wręcz do powrotu. Natomiast לְ (lek $k \hat{u}-$ „idźcie”) wskazuje na coś przeciwnego: wolą mówiącego jest fizyczne oddalenie adresatów od siebie.

Kolejnym problemem jest wyrażenie przyimkowe ('êlay - „do mnie"), które w nowożytnych tłumaczeniach zwyczajowo łączy się z imperativem לִ לִ (lek $k \hat{u})$ - ,przyjdźcie do mnie”. Takie połączenie miałoby sens, gdyby: לִ (lekk̂u) rzeczywiście oznaczało „,przyjdźcie”. ${ }^{6}$ Tymczasem od strony syntaktycznej i semantycznej ('êlay) jest

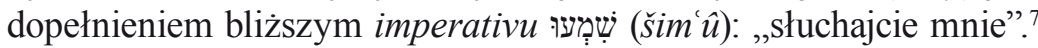
Czasownik שׁَِ (šâma) bardzo często ma dopełnienie w wyrażeniu przyimkowym z אֶ (zob. u samego Deuteroizajasza Iz 46,3.12; 48,12; 49,$1 ; 51,1.7$; i co ważne w wersecie poprzedzającym $55,2 \mathrm{~b}$; ale też w Rdz 16,11; 21,17b; 23,16; 28,7; 49,2; Wj 7,13.22; 8,11.15; Pwt 13,4.9; Joz 1,17: $1 \mathrm{Krl} 8,30$; Iz 36,16 itd.). אֵַ ('élay - „mnie”) zastępuje ac-

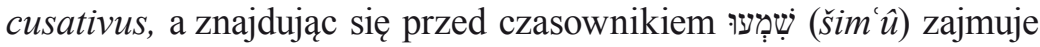
pozycję emfatyczną, co w tłumaczeniu należy podkreślić (np. za pomocą przysłówka wyodrębniającego „tylko”: „tylko mnie słuchajcie”).

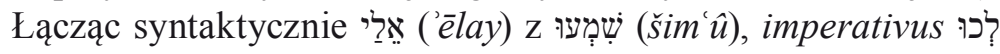
( $\left.l^{e} \underline{k} \hat{u}\right)$ zostaje pozbawiony okolicznika celu, który określiłby kierunek wyrażonej czynności. I rzeczywiście rodzi się pytanie: Dokąd adresaci wezwania mieliby się udać?

Tak oto tłumaczenie, kłopotliwa pozycja z punktu widzenia logiki zdania i przede wszystkim brak okolicznika kierunku sprawiają, że imperativus לִּ (lek̂u) jest albo zbędny i świadczy o skażeniu tekstu

6 Tylko raz w Biblii Hebrajskiej imperativus od אלָר łączy się z 17,44 Goliat zwraca się do Dawida słowami לִכָה אָלֵי Warto jednak zwrócić uwagę, że jest to zdanie warunkowe wprowadzone asyndetycznie i oznacza „Rusz się tylko w moją stronę, a...” Trudno widzieć tu zachętę czy rozkaz do skrócenia dystansu.

Tak wydaje się też sugerować Biblia Tysiąclecia, chociaż postrzega אֵ w w po-

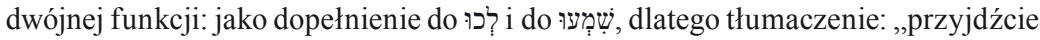
do Mnie i posłuchajcie Mnie".

8 Czasownik שֵַָׁ może mieć dopełnienie również w wyrażeniu przyimkowym

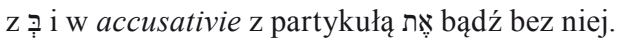


w procesie przekazu, albo jego funkcja wychodzi poza pole semantyczne, jakie przypisuje mu się w słownikach. ${ }^{9}$

\section{Starożytne próby rozwiązania problemu}

LXX rozwiązuje problem, rozszerzając zdanie o okolicznik celu

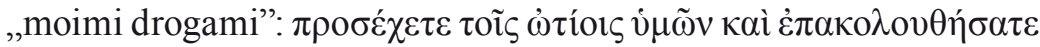

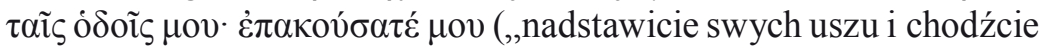
mo i m i d roga m i: posłuchajcie mnie"). W ten sposób LXX za

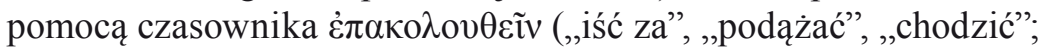

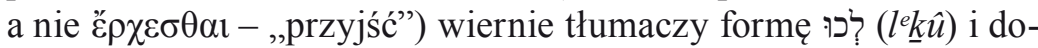
daje do niej brakujący okolicznik, z drugiej zaś strony prawidłowo

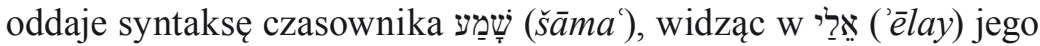

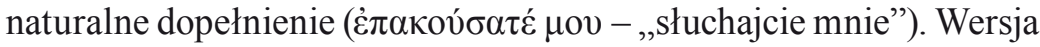
grecka LXX jest raczej próbą salomonowego rozwiązania problemu z czasownikiem לִ לִּ (lek̂u) niż świadectwem na istnienie tradycji paralelnej do TM.

Inną próbą rozwiązania problemu jest 1QIsa (45:22-23), który w od-

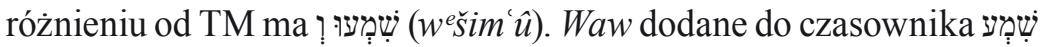

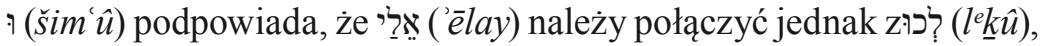
co można by było oddać po polsku ,podążajcie w moim kierunku” (zob. analogia z $1 \mathrm{Sm}$ 17,44; zob. też przyp. 8), natomiast dopełnienie bliższe czasownika שְְִׁעוּ (šim $\hat{u}$ ) byłoby domyślne. W porównaniu z lekcją 1QIs ${ }^{\text {a }}$ (45:22-23), wersja TM jest jednak preferowana jako lectio difficilior i zgodna z syntaksą hebrajską.

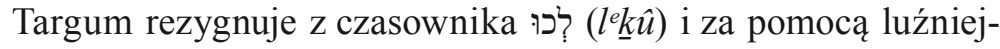

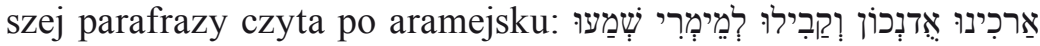

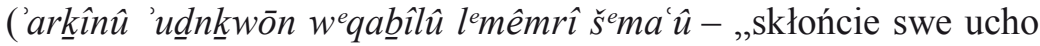
i przyjmijcie moje Memra [słowo], słuchajcie, żeby...”). Ponieważ targum nie przedstawia dosłownego tłumaczenia tekstu hebrajskiego, próby poprawy TM na jego podstawie ${ }^{10}$ lub sugestia,

9 Problem z לִכ w Iz 55,3a zauważa W. A. M. B e u k e n, The Confession of God's Exclusivity by All Mankind, Bijdragen 35/1974, s. 353, przyp. 20.

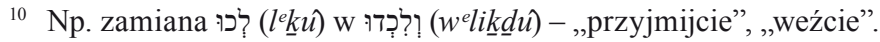


że TM jest skażony, nie mają wiarygodnego podparcia. Tym bardziej że LXX i manuskrypty z Qumran potwierdzają obecność לִ (lek w tzw. dojrzałej formie Księgi Izajasza, poświadczonej przez TM. ${ }^{11}$

\section{Syntaktyczna rola לִ w Iz 55,3a}

Ponieważ próby korygowania TM nie przekonują, wydaje się, że czasownik לִ (le $(l k \hat{u})$ w Iz 55,3 pełni raczej specyficzną funkcję syntaktyczną, i jego obecność w zdaniu nie ma tu większego związku

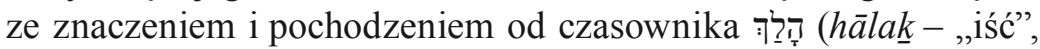
„chodzić”). Forma לִ (lek $k \hat{u})$ miałaby więc charakter czasownika posiłkowego, który podobnie jak inne czasowniki ruchu wzmacnia tryb wolitywny, w tym przypadku imperativus, bądź pełni rolę zachęcającego wykrzyknienia. ${ }^{12}$ Ma na celu wywarcie delikatnej

11 1QIs ${ }^{\mathrm{a}}$ (45:22-23) z II w. przed Chr.:

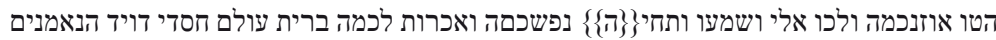
cyt za: M. B u r r o w s (red.), The Dead Sea Scrolls of St. Mark's Monastery, New Haven 1950, plansze I-LIV.

1QIs ${ }^{\mathrm{b}}$ (=1Q8 24:1-2) z drugiej połowy I w. przed Chr.:

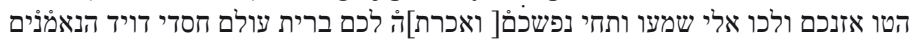

cyt za: E. L. S u k e n i k (red.), The Dead Sea Scrolls of the Hebrew University, Jerusalem 1955, s. 30-34, plansze I-XV, ilust. 10, 18-21; D. B a r th è 1 e $\mathrm{m} y$, Discoveries in the Judean Desert, Oxford 1955-2002, t. 1, s. 66-68, plansza XII.

Świadectwo LXX i Qumran potwierdza istnienie tekstu w tzw. formie dojrzałej (advanced form), czyli w formie pochodzącej z ostatniego etapu kompozycji, co sprawia, że dana księga prorocka daje się rozpoznać w całości jako taka, mimo istnienia licznych wariantów w różnych manuskryptach. Istnienie wariantów uniemożliwia bowiem określenie, która z wersji poświadczona w manuskryptach jest tzw. formą ostateczną (final form). O różnicy między advanced form i final form, zob. M. N i s s i n e n, How Prophecy Became Literature, SJOT 19/2005, s. 153-172.

12 Taką wzmacniającą funkcję formy İָ̧idać szczególnie przy cohortativie, gdzie 2 os. pl. nie zgadza się z następującą po niej formą cohortativu w 1 os. pl.: np. w 1Sm 9,9 וְנְלָכה לְכוף ,dalejże, chodźmy” (zob. też Sdz 19,13; Iz 1,18; Ps 95,1 itp.): „The effect of the plural cohortative is frequently heightened by a verb of motion in the imperative, which functions as an auxiliary or interjection"; B. K. W a $1 \mathrm{t} \mathrm{k} \mathrm{e,}$ M. O' C o n n o r, An Introduction to Biblical Hebrew Syntax, Winiona Lake 1990, s. 547. 
presji na słuchaczu, żeby się zmobilizował i dał się przekonać do szybkiego urzeczywistnienia usłyszanego wezwania. Można go oddać za pomocą „,nuże”, „dalejże”, „,bez obaw” „z uwagą”. Warto też zauważyć, że forma לִ (lek $k \hat{u}) \mathrm{w}$ identycznej funkcji syntaktycznej występuje w Iz 55,1, który wprowadza całą perykopę Iz 55,1-5, w tym omawiane przez nas wersety.

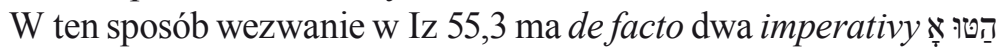

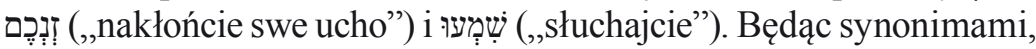
tworzą typowy dla poezji hebrajskiej mądrościowo-prorockiej paralelizm synonimiczny, który pojawia się 11x w Starym Testamencie w szczególności u proroka Jeremiasza (2Krl 19,16; Iz 37,17; Jr 7,24.26; 11,8; 17,23; 34,14; 44,5; Ps 45,11; 78,1; Dn 9,18; zob. też Ps 54,4).

Tłumaczenie, jakie się narzuca, powinno brzmieć: „Skłońcie swe ucho i bez obaw (tylko) mnie słuchajcie".

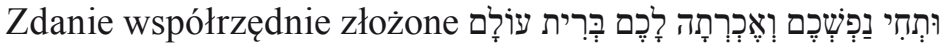 w Iz 55,3b}

Forma apocopata תִ ( $\left.\underline{t}^{e} h \hat{\imath}\right)$ na początku w. 3b pochodzi od czasownika חָיָָ (hāyāh - ,żyć”) i w zdaniu hebrajskim może pełnić dwojaką

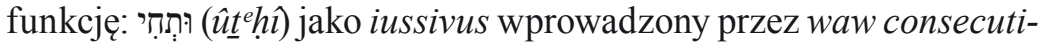
vum (łacząco-skutkowe) zależne od poprzedzającego imperativu

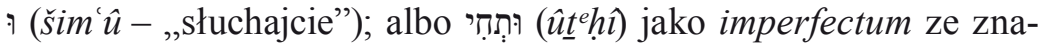
czeniem czasu przeszłego dokonanego ${ }^{13}$ wprowadzone przez waw consecutivum epexegeticum. Nie wykluczone, że jako imperfectum :

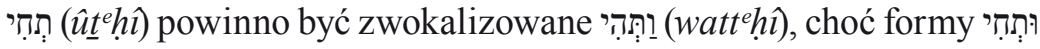

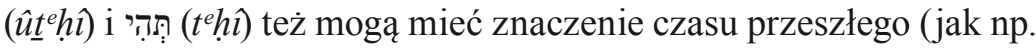
w Pwt 32,18-19; Pwt 32,13) bądź znaczenie perfectum gnomicznego (jak np. w Ps 90,3; 104,20; Za 9,5a).

13 Tamże, s. 469: „The short form (...) denotes either jussive mood or preterite action". Mniej precyzyjnie podobną tezę wyraża W. G e s e n i u s, E. K a u t z s c h, A. E. C ow le y, Hebrew Grammar, Oxford 1910, s. 323, §109k: ,... in not a few cases, the jussive is used, without collateral sense, for the ordinary imperfect form". 
Większość nowożytnych tłumaczeń wybiera tę opcję, łącząc

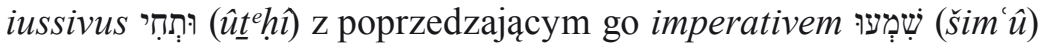
w ciągu przyczynowo-skutkowym (,słuchajcie mnie, a dusza wasza żyć będzie"; lub „słuchajcie mnie, abyście żyli). ${ }^{14}$ Tego typu zdanie ma charakter typowo mądrościowo-prorocki (Prz 9,6; Rdz 42,18; $2 \mathrm{Krl}$ 18,32; Jr 27,12; Am 5,4.6; zob. też J 14,19; Rz 8,13), i u Deuteroizajasza odpowiada przekonaniu, że słowo Boże w samym akcie mówienia i słuchania objawia swoją skuteczność (zob. Iz 55,10n.). Oznaczałoby to, że zarówno życie na wygnaniu, jak i ocalenie z niewoli babilońskiej jest bezpośrednim następstwem sprawczego działania Boga, który, komunikując swój zbawczy plan, jednocześnie go realizuje. Objawienie staje się zbawieniem, a człowiekowi pozostaje jedynie to objawienie przyjąć i mu zawierzyć. ${ }^{15}$

Takie rozumienie jest możliwe w kontekście całej perykopy Iz 55,1-5, gdzie podmiot mówiący zwraca się do słuchaczy w taki sam sposób, jak robi to uosobiona mądrość w Księdze Przysłów (Prz 9,5n.: „Chodźcie, nasyćcie się moim chlebem, pijcie wino, które zmieszałam. Odrzućcie naiwność, a żyć będziecie"; zob. też Ps 34,11; 66,5.16; Ez 33,30; 39,17; Mt 11,28; Ap 19,17). ${ }^{16}$ Pozytywna odpowiedź na wezwanie Bożej mądrości staje się preludium do wybornej uczty, będącej symbolem szczęścia, osobistego sukcesu i radości w ziemskiej doczesności. Jednak warto zwrócić uwagę, że obietnica życia uwarunkowana jest trybem rozkazującym, który de facto jest wezwaniem do nawrócenia. Dlatego w owym „słuchajcie mnie” możemy dostrzec odniesienie do bojaźni Bożej i do oparcia swego życia na fundamencie synajskiego prawa.

14 Zob. Biblia Tysiąclecia, wyd. V popr.

15 E. Z e n g e r, „Hört auf dass ihr lebt“ (Isa 55:3): Alttestamentliche Hinweise zu einer Theologie des Gotteswortes, w: J. S c h r e i n e r (red.), In Freude am Gottesdienst (Festschrift J. G. Plöger), Stuttgart 1983, s. 133-144.

16 Pierwszy zauważył związek Iz 55,1-3 z Prz 9 J. B e g r i c h, Studien zu Deuterojesaja, Stuttgart 1938, s. 59-61. 


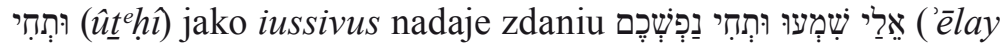
šim' û ûtehî nap̌̌ škem - ,tylko mnie słuchajcie, a dusza wasza będzie”) wydźwięk mądrościowy i choć w pełni odpowiada to hebrajskiej syntaksie i odzwierciedla tradycję Starego Testamentu, opartą na teologii przymierza synajskiego, to jednak nie do końca współgra

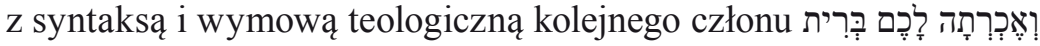

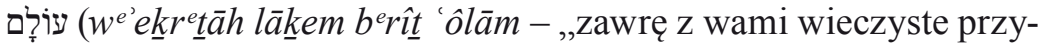
mierze"). Poza tym zbawienie uwarunkowane nawróceniem kłóci się z Iz 44,22 (,powróć do Mnie, bom cię odkupił”), gdzie prorok wywraca tradycyjny porządek teologiczny i zamiast je warunkować, ukazuje zbawienie jako czysty akt Bożej łaski uprzedzający ludzkie nawrócenie. Innymi słowy, jak połączyć w ciągu przyczynowo-skutkowym tryb rozkazujący „słuchajcie mnie, a żyć będziecie” z trybem wolitywnym „chcę zawrzeć z wami przymierze”, i odnaleźć w tym zdaniu jakąś logiczną i teologiczną spójność? Dlatego warto rozważyć inną opcję syntaktyczną.

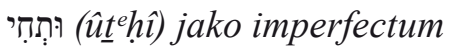

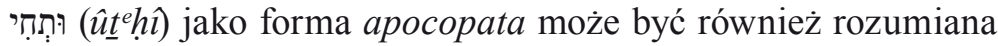
jako imperfectum ze znaczeniem czasu przeszłego dokonanego. Nieprzypadkowo imperfectum apocopatum służy w języku hebrajskim do tworzenia tzw. imperfectum inversivum, które zwyczajowo thumaczy się przez czas przeszły dokonany. Co więcej, w gramatykach historycznych na podstawie porównania z innymi językami semickimi północno-zachodnimi, takimi jak język ugarycki, forma apocopata jest dowodem na istnienie w języku hebrajskim pierwotnie dwóch odrębnych form imperfectum: imperfectum dłuższego i imperfectum krótszego, z których to ostatnie przetrwało w szczątkowej formie jako imperfectum apocopatum ze swoją podwójną funkcją iussivu i czasu przeszłego dokonanego. ${ }^{17}$ Potwierdzeniem, że imperfectum apocopatum może mieć znaczenie czasu przeszłego dokonanego, są

17 Dogłębna analiza problemu w: B. K. Wa $1 \mathrm{tke}$, M. O' Co n nor, An Introduction to Biblical Hebrew Syntax, s. 466-470, zwł. s. 469. 
wspomniane przykładowo teksty: Pwt 32, 13. 18-19; Ps 90,3; 104,20; Za 9,5a. ${ }^{18}$

Nawiązując do powyższej teorii, należałoby zinterpretować formę

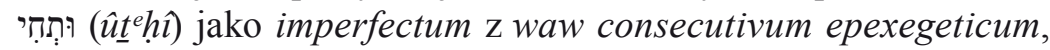
które wprowadzałoby nowe zdanie wyjaśniające. To zdanie, choć syntaktycznie niezależne od poprzedzającego je trybu rozkazującego שְִׁמעוּ (šim ' $\hat{u}$ - ,słuchajcie”), logicznie byłoby jego dopełnieniem, bo przekazywałoby treść Bożego przesłania. Nie chodziłoby więc o uniwersalistyczne wezwanie, typowe dla literatury mądrościowej, żeby słuchać Boga i postępować jego ścieżkami (tymi - ma się rozumieć które zostały ustalone w Torze), ale raczej chodziłoby o konkretną treść, w której centrum znajdowałoby się uroczyste obwieszczenie „ocaliliście swe życie, ponieważ chcę zawrzeć z wami wieczne przymierze" (albo jako perfectum gnomiczne „dalej żyjecie, ponieważ chcę zawrzeć z wami wieczne przymierze"). Taka wieść, żeby znaleźć pozytywny oddźwięk w sercach słuchaczy, musiała być wiarygodna, czyli związana z ich realnym, historycznym doświadczeniem, którym był - mając na uwadze czas powstania Księgi Deuteroizajasza (Iz 40-55) - zwycięski pochód perskiego króla, Cyrusa (lata 550-539 przed Chr.). To, z kolei, wyjaśnia zarówno radosny i podniosły ton całej perykopy Iz 55,1-5, jak i powód do entuzjastycznego świętowania: Bóg dał nam przetrwać okres niewoli, ponieważ, oto teraz, chce z nami zawrzeć wieczne przymierze!

W odróżnieniu od tłumaczenia, omówionego już wyżej, tryb rozkazujący „słuchajcie” nie warunkuje daru życia, ale jest wstępem do ogłoszenia radosnej nowiny - „ewangelii”, której pierwszym

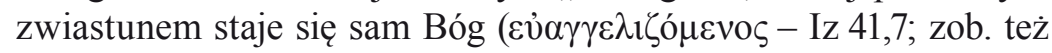
Iz 52,7-9), ukazujący jej ostateczny cel: zawarcie wiecznego przymierza. Logika Jego wypowiedzi potwierdzona jest syntaksą, gdzie cohortativus - w konstrukcji imperfectum + waw consecutivum + cohortativus - wyraża aspekt przyczynowo-skutkowy, przybierając

18 Zob. też tłumaczenie Ps 90,3 i 104,20 w LXX. 
nawet sens zdania warunkowego (jak np. w Iz 27,4; Jr 9,1). ${ }^{19}$ Dlatego możliwe są dwa tłumaczenia: przyczynowe - ,żyjecie, bo chcę zawrzeć z wami wieczne przymierze"; warunkowe - ,jeśli żyjecie, to dlatego że chcę zawrzeć z wami wieczne przymierze".

\section{Ocena dwóch alternatyw}

Dwa powyższe podparagrafy przedstawiają dwie syntaktycznie

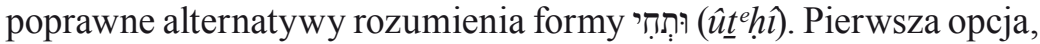
preferowana przez komentatorów, podkreśla aspekt mądrościowy i uzależnia życie wygnańców od ich woli i nawrócenia. Druga stawia w centrum Bożą łaskę, która objawia się w niezasłużonym darze życia, otwierającym ponadto perspektywę wiecznego przymierza. Ponieważ druga interpretacja współgra z teologią Deuteroizajasza i lepiej oddaje sens perykopy Iz 55,1-5, to właśnie ona będzie przesłanką dalszej analizy.

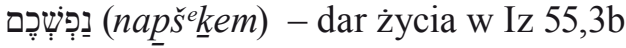

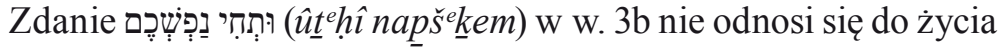
nadprzyrodzonego, co sugerują współczesne tłumaczenia (,„... a dusza wasza żyć będzie”), uświęcone łacińską tradycją Wulgaty (,...et vivet anima vestra"). ${ }^{20}$ Chodzi tu o życie naturalne, które wyszło od Stwórcy, zgodnie z opisem Księgi Rodzaju. Rzeczownik נְֶֶּ (nepeš) w połączeniu z czasownikiem חָזָָ (hāyahh) pełni funkcję zaimka osobowego $^{21}$ i oznacza po prostu ,żyć” lub - jeżeli kontekst niebezpieczeństwa i zagrożenia życia to sugeruje - ,ocalić swe życie” (zob. np. Rdz 12,13; 19,19.20; $1 \mathrm{Krl}$ 20,31.32; Jr 21,9; 38,2.17.20; Ez 3,21; 13,19;

19 P. J o ü o n, Grammaire de l'hébreu biblique, Roma 1923, s. 314-316; B. K. Wa lt k e, M. O' C o n n o r, An Introduction to Biblical Hebrew Syntax, s. 575 n.

20 Podobnie uważa K. B a 1 t z e r, Deutero-Isaiah, Minneapolis 1999, s. 469.

${ }_{21}$ R. L. H a r r i s, G. L. A r c h e r, B. K. W a l t ke (red.), Theological Wordbook of the Old Testament, Chicago 1980, t. 2, s. 589. 
Ps 119,175). Dlatego tłumaczenie „ocaliliście swe życie” w w. 3b najlepiej oddaje sytuację żydowskich wygnańców w Babilonii w połowie V w. przed Chr.

Ponadto w odróżnieniu od abstrakcyjnego rzeczownika חַיִים (hayyîm), oznaczającego ,życie” w sensie rozciągłości czasowej i biologicznego trwania, נֶֶֶ (nepeš) wyraża osobową egzystencję z jej pragnieniami, inklinacjami, planami na przyszłość i ludzkim dążeniem do samorealizacji. Jest więc całkowitym zaprzeczeniem śmierci. ${ }^{22}$ Jeśli Bóg mówi „ocaliliście swe życie”, skłania swych słuchaczy do głębszej refleksji nad sytuacją, w jakiej się znaleźli, i nad perspektywami pełnymi nadziei, jakie się przed nimi otwierają. Teraz są ,świętą Resztą", i choć od zawsze było to wpisane w tajemniczy plan, który realizuje się na ich oczach zgodnie z zapowiedzią Izajasza w VIII w. (Iz 28,21; 37,26; zob. też Iz 22,11 i ,apokalipsa” Izajasza w Iz 25,1), powinni przeżywać swe życie jako niezasłużony dar i jako podstawę do nawiązania nowej relacji z Bogiem: „ocaliliście swe życie, bo chcę zawrzeć z wami wieczne przymierze".

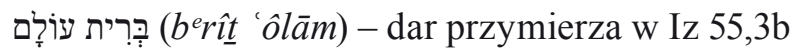

„Wieczne przymierze” w w. 3b może być rozumiane dwojako: jako „przymierze, które będzie trwało wiecznie” (עוֹלָם 'ôlām - genetivus adiectivalis mensurae), albo jako ,przymierze, które trwało od wieków” (ערוֹ 'ôlàm - genetivus adiectivalis attributivus ${ }^{23}$ ).

W pierwszym rozumieniu chodziłoby o nowe przymierze albo o nowy jego wymiar, dotychczas nieznany, a tu wyrażony w nieprzerwanej ciągłości jego trwania. W drugim rozumieniu chodziłoby o odnowienie przymierza, które obowiązywało od wieków, i choć z winy człowieka zostało zerwane, z perspektywy wiernego Boga nadal pozostaje płaszczyzną nawiązania nowej relacji. Skoro w teologii

22 Tamże, s. 590.

${ }^{23}$ Choć ערוֹ - ôlām w drugiej opcji też podkreśla aspekt czasowy, to jednak wyraża go jako cechę istotową bądź nabytą na przestrzeni wieków. Dlatego syntaktycznie עוֹרָ to genetivus attributivus. 


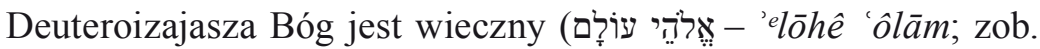
Iz 40,28), Jego przymierze też zachowuje tę prerogatywę (Iz 55,3c).

Od odpowiedzi na pytanie, która z powyższych opcji odpowiada zamysłowi autora, zależy zrozumienie prorockiego przesłania. Jednak problem polega na tym, że za każdą z tych dwóch opcji przemawiają mocne argumenty. Za nowym przymierzem przemawia nieokre-

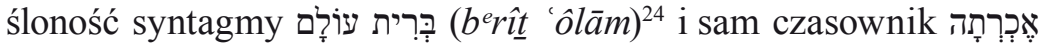
('ekr ${ }^{e} \underline{t} a \bar{h}$ - „zawrę"); trudno bowiem zawierać przymierze, które już zostało zawarte. Za starym przymierzem przemawia niezmienność łaski udzielonej niegdyś Dawidowi, o której mówi w. 3c (2Sm 23,5).

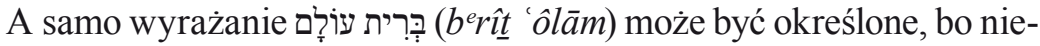
które instytucje religijne (np. namiot spotkania) w języku hebrajskim pojawiają się bez rodzajnika. ${ }^{25}$ Ponadto większą siłę perswazji w uszach wygnańców musiało mieć odniesienie do starego proroctwa Natana, gdzie Bóg uroczyście przysiągł Dawidowi wieczne panowanie (2Sm 7,12-13.15-16: „Przede Mną dom twój i twoje królestwo będzie trwać na wieki”) ${ }^{26}$ Z kolei, obietnica nowego „wiecznego" przymierza, skoro stare się nie wypełniło, byłaby mniej wiarygodna, a nawet groteskowa.

Odkładając na bok chrystologiczną interpretację Ojców Kościoła, ${ }^{27}$ obecną już - rzecz jasna - w Nowym Testamencie (zob. Dz 13,34),

24 Gdyby chodziło o przymierze, nawiązujące jednoznacznie do przeszłości, należałoby oczekiwać formy z rodzajnikiem הָעוֹ (hā ôlām) - jak w Jr 28,8; J1 2,2; Dn 12,7 .

25 B. K. W a 1 t k e, M. O' C o n n o r, An Introduction to Biblical Hebrew Syntax, s. 240.

26 Proroctwo Natana (2Sm 7), poddane obróbce deuteronomistycznej i włączone do DtrH, jest bardzo starożytnym tekstem, który odcisnął swe piętno na późniejszych nadziejach mesjańskich. Wiele innych tekstów biblijnych mówi o prawowitej władzy Dawida i trwaniu jego królestwa (1Sm 13,13n.; 28,17n.; 23,17; 24,21; 25,28.30; 2Sm 3,9n.18; 5,1n.; 6,21a); zob. R. S m e n d, La formazione dell'Antico Testamento, Brescia 1993, s. 157-158.

27 Tylko trzech Ojców Kościoła skupiło swą uwagę na Iz 55,3: Teodor z Heraklei († 355 r.), św. Hieronim († 420 r.) i Teodoret z Cyru († 466 r.). Pierwszy z nich podkreśla aspekt słuchania, od którego zależy skuteczność Bożej łaski; zob. J.-P. M i g n e (red.), Patrologia cursus completus. Series Graeca, t. 18, Paris 1857-1886, kol. 1360-1361. Drugi widzi tu zapowiedź nadejścia „nowego Dawida”, co 
i bazując jedynie na tekście biblijnym, brak jednoznacznego stanowiska w omawianej kwestii prowadzi tylko do jednej konkluzji: „wieczne przymierze” w Iz 55,3b zawiera w sobie jednocześnie element kontynuacji i dyskontynuacji. Kontynuacji z tradycją Dawida (w. 3c) i dyskontynuacji (ww. 4-5), która wyraża się w wyjątkowym „świadectwie” wygnańców (עֵ ‘ 'e $\underline{e}$ ) i w ich bezprecedensowej pozycji wśród „ludów” לִ (le'ummîm). Wygnańcy stają się adresatami i beneficjentami tak rozumianego przymierza, co potwierdza zaimek osobowy לְָ (lākem) w celowniku, tłumaczony jako dativus relationis (,z wami”) bądź jako dativus commodi (,dla waszego dobra”).

$\mathrm{Z}$ takiej perspektywy podmiotem mówiącym w 1 os. 1. poj. (,za-

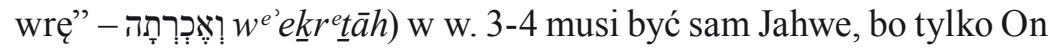
w teologii Deuteroizajasza, jak i całego Starego Testamentu, może być oferentem i gwarantem wiecznego przymierza.

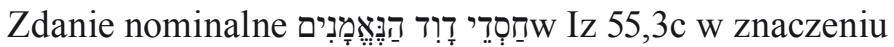 przyczynowym lub skutkowym}

Zdanie nominalne w w. 3c odpowiada na pytanie: Jaki jest pod-

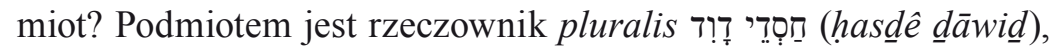

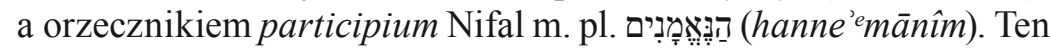
typ zdań charakteryzuje się szykiem: orzecznik + podmiot. ${ }^{28}$ Ponieważ ten szyk jest tutaj odwrócony, zdanie znajduje się w pozycji rozłączonej w stosunku do zdania poprzedzającego i może mieć sens

wypełni się w Ewangelii; zob. H i e r o n y m u s, Commentarium in Isaia Prophetam Libri Duodeviginti, 15.12, w: Aus der Geschichte der lateinischen Bibel, Freiburg 1957-, t. 35, kol. 1575. Trzeci podkreśla wypełnienie się przymierza Dawidowego w tajemnicy wcielenia; zob. Th è o d o r e t d e C y r, Commentaire sur Isaïe, 17.55.2-3, w: H. d e L u b a c, J. D a n i è l o u i in. (red.), Sources Chrétiennes, Paris 1941-, s. 315.178.

${ }^{28}$ „In a verbless clause of classification in which the predicate refers to a general class of which the subject is a member, the two parts of the clause generelly occur in the order predicte-subject. Clauses of classification answer the question What is the subject like?'; B. K. W a $1 \mathrm{t}$ k e, M. O' C o n n o r, An Introduction to Biblical Hebrew Syntax, s. 132-133. 
przyczynowy z czasem teraźniejszym lub skutkowy z czasem przyszłym (, ,...ponieważ łaski dla Dawida są niezawodne"; lub ,... a łaski Dawida pozostaną niezmienne"). ${ }^{29}$ Tłumaczenie przyczynowe lub skutkowe zdania nominalnego w w. 3c zależy od rodzajnika okre-

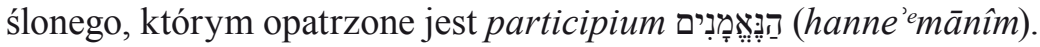
Innymi słowy, należy odpowiedzieć na pytanie, czy jest to rodzajnik anaforyczny, czy kataforyczny.

Rozumiany anaforycznie rodzajnik odnosiłby się do wcześniejszej wzmianki o łaskach Dawida, której w poprzedzającym kontekście literackim nie było. Ale rodzajnik anaforyczny może odnosić się też do szerszego kontekstu kulturowego i religijnego, który jest wystarczający, żeby adresaci proroka mogli tę aluzję zrozumieć. Biblia Hebrajska potwierdza, że „odwieczne łaski dla Dawida” są stałym toposem teologiczno-literackim, opartym na proroctwie Natana (zob. 2Sm 7,12-13.15-16; 23,5; Ps 89,29.50; 2Krn 6,42; zob. też Ps 25,6; 106,45). Z tego wynika przyczynowe tłumaczenie całego zdania: „... ponieważ łaski Dawida pozostają te same, niezmienne”. Podstawą przymierza są obietnice dane Dawidowi. A sam Dawid postrzegany jest jako postać indywidualna i stricte historyczna.

Rozumiany kataforycznie rodzajnik wybiegałby swym znaczeniem niejako do przodu i antycypował opis, który powinien pojawić się w kolejnym zdaniu. W takim przypadku rodzajnik kataforyczny byłby ściśle związany z w. 4 i tam znajdował podstawę swej określoności. Z tego wynika skutkowe tłumaczenie zdania: ,... a łaski dla Dawida pozostaną niezmienne, a mianowicie to, że ustanawiam go świadkiem dla narodów”. Zapewnienie o trwałych skutkach przymierza nadaje postaci Dawida i roli, jaką Bóg mu wyznaczył, wymiar wykraczający poza historyczne ramy jego panowania i otwiera perspektywę przyszłości, w której adresaci muszą utożsamić się z samym Dawidem jako jego potomstwo, jako spadkobiercy jego mesjańskiej

${ }^{29} \mathrm{~W}$ językach nowożytnych zdania nominalne w szyku rozłączonym są typowe dla języka mówionego. Np. w sekwencji „Daj mi jeść. Jestem głodny”, zdanie nominalne „Jestem głodny” ma wyraźnie znaczenie przyczynowe. W języku hebrajskim jest to zwyczajowy sposób wyrażania myśli. 
misji i jako wspólnota eschatologiczna pośród narodów, na której obietnice dane Dawidowi konkretnie się wypełniają. Katafora nadaje więc Dawidowi znaczenie kolektywne i eschatologizujące.

Trudno rozstrzygnąć, które użycie rodzajnika (anaforyczne czy kataforyczne) jest tutaj bardziej odpowiednie. Wszystko wskazuje jednak na to, że ta dwuznaczność jest zamierzona w intencji autora i podobnie jak ,wieczne przymierze" niesie w sobie element kontynuacji (Dawid - postać indywidualna i historyczna) i dyskontynuacji (Dawid - postać kolektywna i eschatologiczna).

Ta otwartość w. 3c na znaczenie przyczynowe i skutkowe utrudnia jego jednoznaczne tłumaczenie w języku polskim, dlatego najlepszym rozwiązaniem będzie użycie partykuły „zaiste”, która potwierdza prawdziwość wypowiadanego sądu i ma w sobie zawoalowany aspekt przyczynowy i skutkowy.

Pluralis חַ (has dê ê) jest tzw. zintensyfikowaną liczbą mnogą i, pochodząc od rzeczownika (hese $\underline{\text { d }}$ ), wyraża w tym przypadku bogactwo łaski i ogrom miłości. ${ }^{30}$ Ponieważ w teologii Starego Testamentu

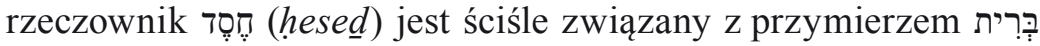
( $\left.b^{e} r \underline{\hat{t}}\right)$, oba terminy są teologicznie pokrewne i można je traktować zamiennie. ${ }^{31}$ Jeśli życia Boga z człowiekiem, to חֶֶ? (hese $\underline{\text { d }}$ ) tę przestrzeń wypełnia i nadaje jej sens, podobnie jak instytucja małżeństwa otwiera właściwą przestrzeń dla miłości mężczyzny i kobiety. I nieprzypadkowo metafora małżeńska będzie w starotestamentowej literaturze prorockiej

30 D. W. T h o m s o n, A Consideration of Some Unusual Ways of Expressing the Superlative in Hebrew, VT 3/1953, s. 209-224; t e n ż e, Some Further Remarks on Unusual Ways Expressing the Superlative in Hebrew, VT 18/1968, s. 120-124.

31 N. G 1 ü c k, Das Wort hesed im alttestamentlichen Sprachgebrauche als menschliche und göttliche gemeinschaftgemässe Verhaltungsweise, Berlin 1961², s. 10-16 (tł. ang. Hesed in the Bible, Cincinnati 1967). T. I s h i d a. The Royal Dynasties in Ancient Israel. A Study on the Formation and Development of Royal-Dynastic Ideology, Berlin-New York 1977, s. 109. Krytyka stanowiska Glücka zob. H.J. Z o b e 1, hesed, w: G. J. B o t t e r w e c k, H. R i ng g r e $\mathrm{n}$ i in. (red.), Grande Lessico dell'Antico Testamento, t. III, Brescia 2003, kol. 67-69: ,...hesed descrive il comportamento adeguato alla vita in una comunità". 
najskuteczniejszym obrazem ukazującym istotę przymierza z Bogiem

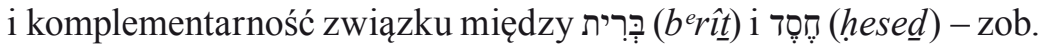
Jr 31,3; Oz 11,4: Mi 6,8.

Skoro dynamika przymierza opiera się na wzajemności praw i obowiązków, słowo חֶֶ? (hesed ) może wyrażać jednocześnie miłość Boga do człowieka i miłość człowieka do Boga. A zatem w Iz 55,3c imię Dawida w wyrażeniu חָọ (has genetivus subiectivus (miłość Dawida do Boga), albo jako genetivus obiectivus (miłość Boga do Dawida). A ponieważ w kontekście omawianej perykopy na pierwszym planie znajduje się łaska Boża, której wyrazem były obietnice złożone Dawidowi w 2Sm 7,10-16

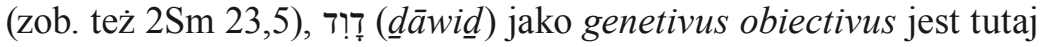
opcją lepszą, jak się wydaje, bardziej odpowiadającą myśli autora.

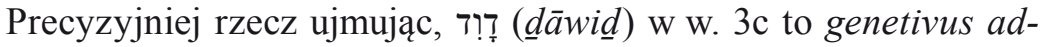
verbialis commodi (podkategoria w składni genetivus obiectivus), ${ }^{32}$ ponieważ przez swe obietnice Bóg żywo zaangażował się na rzecz królestwa Dawida i trwałego umocnienia jego dynastii. Z tego płynie tłumaczenie celownikowe: „obfitość łask dla Dawida”. Tak też uważa większość biblistów, ${ }^{33}$ choć ich argumenty opierają się bardziej na

32 „A special genitive of this sort [= the adverbial genitive] is the genitive of advantage (...), in which $\mathrm{G}$ is the recipient or beneficiary of a favorable... action..."; zob. B. K. W a $1 \mathrm{t}$ k e, M. O' C o n n o r, An Introduction to Biblical Hebrew Syntax, s. 147.

33 Taka interpretacja przeważa w egzegezie; zob. dyskusja nad jej słusznością H. G. M. W i 11 i a m s o n, The Sure Mercies of David”: Subjective or Objective Genetive? Journal of Semitic Studies 23/1978, s. 31-49. Jednak niektórzy, idąc za LXX, Peszittą i komentarzem Rasziego, widzą tu genetivus subiectivus auctoris

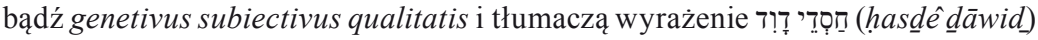
„wierne czyny Dawida” lub ,wierność Dawida”; zob. A. C a q u o t, Les grâces de David. A propos d'Isaïe 55,3b, Semitica 15/1965, s. 45-59; J. M. M y e r s, II Chronicles, Garden City 1965, s. 35; M. A d i n o $1 \mathrm{f} \mathrm{i}$, Le opere di pietà liturgica di David in 2 Cron. 6,42, Bibbia e Oriente 8/1966, s. 31-36; ciekawa jest teza Beukena, który widzi w חָסִדִ (has podobne wyrażenie opisuje czyny Ezechiasza i Jozjasza w 2Krn 32,32; 35,26; zob. W. A. M. B e u k e n, Isa. 55,3-5: the Reinterpretation of David, Bijdragen 35/1974, s. 49-64. W podobnym kierunku idzie interpretacja na podstawie Dokumentu 
tzw. argumentach zewnętrznych ${ }^{34}$ niż na wewnętrznym kontekście teologicznym Iz 55,3-5, który tutaj jest decydujący.

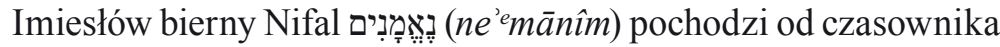
אמן (,,umocnić”, „utwierdzić”, ,być wiernym”, „,być stałym”), ${ }^{35}$ który wykorzystywany w stronie biernej często ma znaczenie tzw. passivum divinum, wskazując na działanie Boga względem człowieka (zob. Iz 1,21.26). Ponieważ tutaj, w Iz 55,3c, podmiotem mówiącym i dzia-

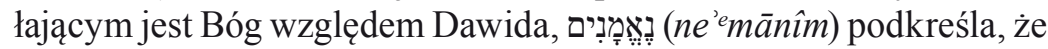
owa przeogromna miłość do Dawida jest trwała bądź niewyczerpana.

Iz 55,4 jako zapowiedź teologicznej nowości

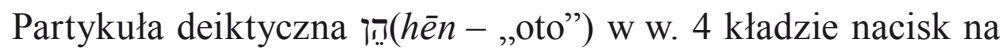
słowo, które po niej następuje (עِ 'êd - „świadek”), i wprowadza uroczystą enuncjację teologicznej nowości, która uobecnia się przed oczami adresatów w czasowej natychmiastowości (zob. Jr 3,22; Iz 6,8; 1Krl 2,29). ${ }^{36}$ Dlatego perfectum נִַּת (netattîw) należy przetłumaczyć jako czas teraźniejszy. Ta enuncjacja i jej natychmiastowa realizacja stoi w pozycji rozłączonej w stosunku do zdania poprzedzającego (w. 3c) jako jego antyteza (,...ponieważ [dawne] łaski dla Dawida pozostają niezmiennie te same. Ale oto [teraz] ustanawiam go świadkiem...”) bądź jako jego wyjaśnienie (,...a [nowe] łaski dla Dawida pozostaną niezmienne, a mianowicie to, że oto [teraz] ustanawiam go świadkiem...”). Różnica w tłumaczeniu w. 4 zależy od sensu poprzedniego zdania (w. 3c).

Damasceńskiego z Qumran (CD 5,5b-6a); zob. J. C. R. D e R o o, David's Deed in the Dead Sea Scrolls, Dead Sea Discoveries 6(1999)1, s. 44-65 (zwł. s. 61-63).

${ }^{34}$ Tzn. rozstrzygająca jest dla nich częstotliwość użycia składni genetivus obiectivus z rzeczownikiem nֶׁ (hesed) w całej Biblii Hebrajskiej i poza nią.

35 L. K o e h l e r, W. B a u m g a r t n e r, J. J. S t a m m, Wielki słownik hebrajsko-polski i aramejsko-polski Starego Testamentu, Prymasowska Seria Biblijna 30, Warszawa 2008, t. 1, s. 62.

$36,[$ [ה]...emphasizes the immediacy, the here-and-now-ness of the situation"; B. K. W a 1 t k e, M. O' C o n n o r, An Introduction to Biblical Hebrew Syntax, s. 675; T. O. L a m b d i n, Wprowadzenie do hebrajskiego biblijnego, Lublin 2012, s. 289. 
Jeśli w. 3c ma sens przyczynowy, w. 4 jest antytezą wprowadzającą nowość w porządku znaczeniowym i czasowym dawnego przymierza (dawna nienaruszalna pozycja Dawida w Izraelu $\leftrightarrow$ obecna pozycja Dawida pośród narodów).

Jeśli w. 3c ma sens skutkowy, w. 4 ma za zadanie wyjaśnić nowość (ה̣ epexegeticum), która byłaby już implicite zawarta w w. 3bc, ale dopiero tutaj zostałaby explicite wyrażona. Bóg, nie oglądając się na stare przymierze, udzieliłby nowej łaski Dawidowi, a mianowicie takiej, że pozycja króla nabierze innych, nieznanych dotąd, konotacji.

Choć oba tłumaczenia podkreślają novum teologiczne, w którego centrum znajduje się „świadectwo pośród narodów”, to jednak drugie tłumaczenie z הן epexegeticum - możliwe syntaktycznie - teologicznie jest niewłaściwe, bo nie dowartościowuje w należyty sposób starego proroctwa Natana, które nadawało przesłaniu Deuteroizajasza wiarygodności i stawiało go w ciągłości z poprzednią przedwygnaniową tradycją. A ta przecież, wśród wygnańców pozbawionych kultu świątynnego, odegrała kluczową rolę w utrzymaniu narodowo-religijnej tożsamości. Z kolei, pierwsze tłumaczenie z antytezą jest bardziej przekonujące, bo odpowiada teologicznej sekwencji: kontynuacja (w. 3) przez dyskontynuację (ww. 4-5), charakterystycznej dla wiary biblijnej Starego i Nowego Testamentu.

\section{Accusativus duplex i specyfika Dawidowego powołania}

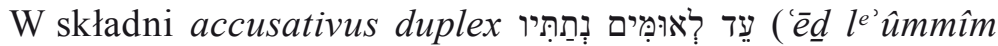
$n^{e} \underline{t a t t \hat{w}}$ - „ustanawiam go świadkiem narodów”) sufiks zaimkowy 3 os. 1. poj. m. jako accusativus obiectivus pełni funkcję dopełnienia

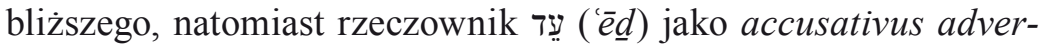
bialis specificationis jest dopełnieniem dalszym. Z kolei, genetivus

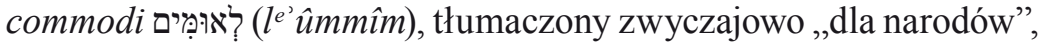

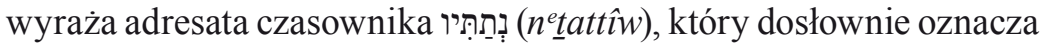
„daję go" (zob. Jr 1,5; Ez 3,17; 28,14; zob. też Rdz 27,37). A zatem tłumaczenie „daję go jako świadka dla narodów” podkreślałoby charakter oblatywny misji, jaką Dawid ma wypełnić na rzecz narodów. 


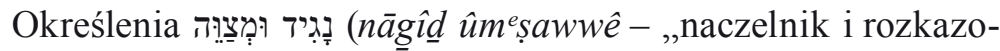
dawca/prawodawca") tworzą tzw. hendiadys, dlatego powinno się tłumaczyć raczej ,główny rozkazodawca/prawodawca". ${ }^{37}$ Owa hendiadys to kolejny accusativus specificationis, zależny od czasownika

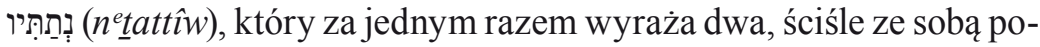

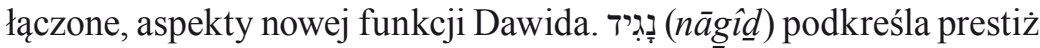
$\mathrm{i}$ autorytet Dawida, związany z odpowiedzialnością i uprzywilejowanym pierwszym miejscem wśród ludów. ${ }^{38} \mathrm{Z}$ kolei, jego rolę prawodawcy na wzór Mojżesza, który obwieszczał wolę Boga w prawie synajskim i wprowadzał Boży ład w społeczne życie Izraela. ${ }^{39}$ Jednak w odróżnieniu od misji Mojżesza, przywódcza rola Dawida ma polegać na poszerzeniu Bożego panowania poza granice etnicznego Izraela i otwierać w kolejnych wersetach (ww. 5-7) perspektywę uniwersalistyczną i eschatologiczno-mesjańską, stając się niemal preludium dla nastania królestwa Bożego na ziemi.

Pierwszeństwo Dawida zasadza się nie tylko na woli Bożej (,ustanawiam go"), ale i na wiernym komunikowaniu Bożego prawa naro-

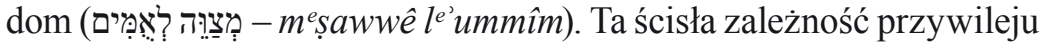
pierwszeństwa od rzetelnie wypełnionej misji podkreśla świadomość o ciążącej na Dawidzie odpowiedzialności za losy świata i poniekąd przywodzi na myśl przypadek króla Saula, który, sprzeniewierzając się Bożemu nakazowi (צוה), został pozbawiony funkcji naczelnego

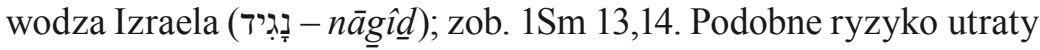
uprzywilejowanej pozycji Izraela kreślił Amos, gdy ironicznie przepowiadał, że przywódcy izraelscy, „książęta pierwszego z narodów” jako pierwsi pójdą na czele wygnańców; zob. Am 6,1.7.

37 Zob. analogia asyndetyczną hendiadys z Jr 20,1 - פָּקיד נָגִיד - „główny zwierzchnik".

38 R. L. Harris, G. L. A r c he r, B. K. Walt ke (red.), Theological Wordbook of the Old Testament, t. 2, s. 549.

39 Nieprzypadkowo rdzeń צוה pojawia się głównie w Księdze Powtórzonego Prawa (88 x jako czasownik i 43 x jako rzeczownik) i w innych księgach Pentateuchu (53 x w Wj; 46 x w Lb; 4 x w Kpł) w odniesieniu do pośrednictwa Mojżesza w przekazie Bożej woli. Zob. też E. J e n n i, C. W e s t e r m a n n, Theological Lexicon of the Old Testament, Peabody, Massachusetts 1997, t. 2, s. 1062. 
Wewnętrzna dynamika w. 3-4, syntaktyczno-gramatyczna i teologiczna, wskazuje więc, że Dawidowy przywilej pierwszeństwa ( ków, których nowy status wśród narodów zostaje usankcjonowany nowym przymierzem. I to w nim wypełnia się proroctwo Natana. Zbieżność czasowa tego przesłania z nastaniem władzy Cyrusa i z otwierającą się przed Żydami perspektywą powrotu do ojczyzny sprawia, że Iz 55,3-5 nadaje teologiczny sens wydarzeniom na scenie międzynarodowej i pozwala Żydom odnaleźć się w zmienionej sytuacji historycznej, która jest kolejnym etapem historii zbawienia, a oni ponownie stają się jej głównymi protagonistami. Innymi słowy, Iz 55,3-5 to manifest określający podstawowy cel i rację by tu Izraela powygnaniowego, który jako Dawid narodów wprowadza ludzkość w doświadczenie Bożego prawa.

Adresat nowego przymierza będzie dla ludów pośrednikiem w poznaniu Bożej woli. Widać to w przejściu od składni dativus commodi „dla was” (לֶָָ lākem) w w. 3b do składni genetivus commodi „dla

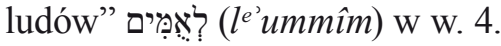

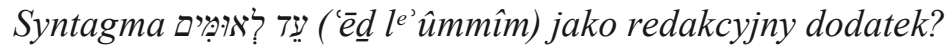

W egzegezie w. 4 trzeba zwrócić uwagę na problematyczny zwią-

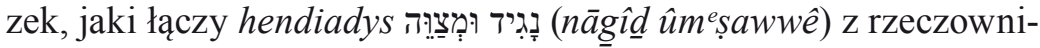
kiem עֵּ ('êd).

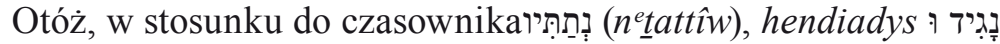

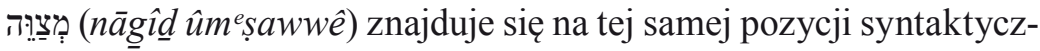
nej co rzeczownik עֵ ('e $(\bar{e})$ ), czyli pełni funkcję accusativus adverbialis specificationis (,....ustanawiam go przywódcą i prawodawcą dla narodów"). Natomiast w stosunku do rzeczownika עֵ ('e sama hendiadys, wprowadzona asyndentycznie, jest apozycją, która sugeruje, że Judejczycy złożą świadectwo nadając narodom Boże prawo. Staną się jego ambasadorami w świecie i będą je egzekwować z pozycji niemalże królewskiej.

Jeśli sposób złożenia świadectwa nie ulega wątpliwości, jego treść pozostaje zagadką. Czego bądź kogo mają być świadkami? 
Z treści poprzedniego wersetu można wywnioskować, że byliby świadkami wierności Boga ${ }^{40}$ który dochował przysięgi złożonej Dawidowi przez usta Natana (w. 3c). Ich pozycja w świecie byłaby żywym dowodem na to, że Bóg nigdy nie opuszcza swego sługi, lecz stale o nim pamięta i w stosownym momencie wywyższa go. ${ }^{41}$ Odpowiadałoby to mądrościowemu przesłaniu Starego Testamentu o Bogu, „który strąca władców z tronu, a wywyższa pokornych”.

Ponadto szerszy kontekst księgi Deuteroizajasza (Iz 43,9-10.12; 44,8-9) sugeruje, że w teologii świadectwa kryje się uroczysta afirmacja jahwistycznego monoteizmu pośród bałwochwalczych narodów i proklamacja o jedyności Boga, Stwórcy i Zbawcy człowieka. Z tej perspektywy Iz 55,4 zapowiadałby, że Judejczycy najpierw będą głosić narodom prawdę o Bogu Jedynym i skłaniać ich do nawrócenia, a potem wprowadzą na ziemi Jego święte prawo.

Brak określoności w rzeczowniku עֵ ('e z dokładnym opisaniem jego znaczenia może być sygnałem, że cała

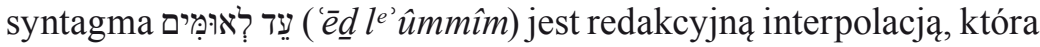
stanowi komentarz lub korektę lapidarnego zdania „ustanowię go przywódcą i prawodawcą dla narodów". ${ }^{42}$

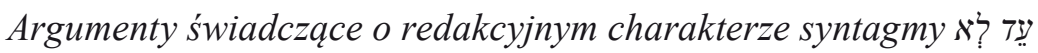

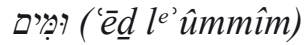

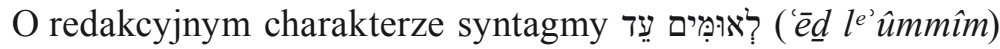

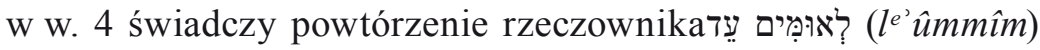
$\mathrm{w}$ funkcji genetivu. Takie powtórzenie tworzy osobliwy szyk ciągu

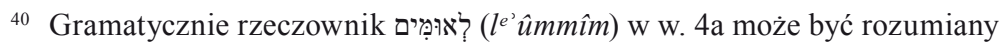

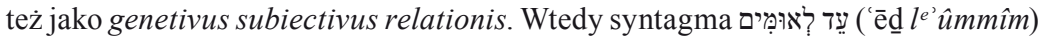
oznaczałaby „świadkowie narodów”. Ale takie wyjaśnienie kłóci się z teologią Deuteroizajasza, dla którego narody są polem konfrontacji/misji dla Izraela, reprezentującego Jahwe, a nie inne ludy.

${ }_{41}$ Trudno, żeby byli świadkami wiecznego przymierza, skoro są jego stroną (w. 3b). Od świadka wymaga się przecież bezstronności.

${ }_{42}$ Problem redakcji Iz 55 potraktowany niebywale zdawkowo przez R. F. M e $1 \mathrm{u} g$ i n, The Formation of Isaiah 40-55, Berlin 1976, s. 173-174. 
dopełniaczowego, w którym dwa rzeczowniki w status constructus

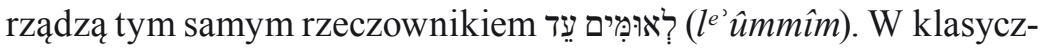
nym szyku drugi genetivus powinien być zastąpiony przez sufiks zaimkowy dołączony do rzeczownika w status absolutus (jak np. w $1 \mathrm{Krl} 8$,28). Paradygmat takiego szyku przedstawia się według schematu: ${ }^{43}$ st. cstr. + gen. + st. abs. + sufiks zaimkowy. A zatem w poprawnej konstrukcji syntaktycznej, Iz 55,4 powinien wyglądać następująco:

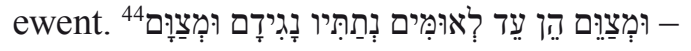
„oto ustanawiam go świadkiem dla ludów jako ich przywódcę i ich prawodawcę"

lub

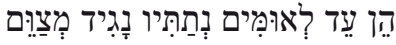

- „oto ustanawiam go świadkiem dla ludów jako ich naczelnego prawodawcę"

Szyk w. 4 w TM, nieprzystający do powyższego schematu, wskazywałby na działalność redaktora, który dodał do niego syntagmę

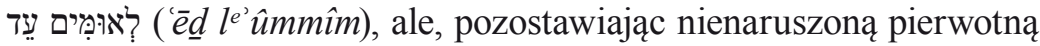
konstrukcję zdania, wprowadził w jego strukturę fałszywą nutę. Warto

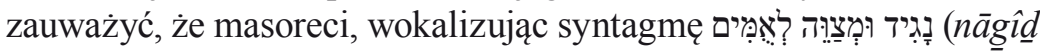
ûmeṣawwê le’ummîm), też przestrzegają zasady, w myśl której genetivus

43 „Most of the construct chains in Biblical Hebrew involve two items, construct or head (C), and genitive or absolute $(\mathrm{G})$. If the head involves two or more nouns rather than one, all but the first come after the genitive, often linked to the head with a pronominal suffix"; B. K. W a $1 \mathrm{t}$ k e, M. O' C o n n o r, An Introduction to Biblical Hebrew Syntax, s. 139.

44 Wokalizacja שָָָׁדה zob. participia Piel czasowników ל"ה z sufiksami w: P. J o ü o n, Grammaire de l'hébreu biblique, s. 245. Jeśli chodzi o wokalizację participiów z sufiksami zob.

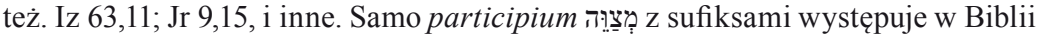
Hebrajskiej 28 x, i co ciekawe, praktycznie tylko w Księdze Powtórzonego Prawa: Wj 34,11; Pwt 4,40; 6,2.6; 7,11; 8,1.11; 10,13; 11,8; 12,14.28; 13,18; 15,5.11.15; 19,7.9; $24,18.22 ; 26,16 ; 27,10 ; 28,1.13 .15 ; 30,2.8 .11 .16$. 
nie może zależeć od dwóch rzeczowników w status constructus. Dlatego pierwszy rzeczownik נִִָּ (nâgîld) jest w status absolutus, a drugi

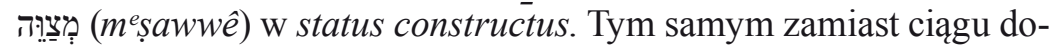
pełniaczowego stworzyli jego odpowiednik - hendiadys.

Innym argumentem wskazującym na redakcyjny charakter syn-

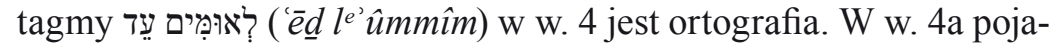

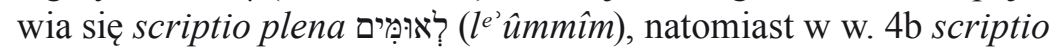

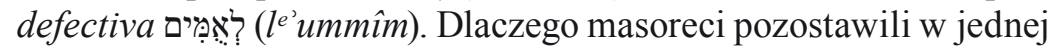
linijce dwie różne pisownie tego samego słowa? Z historii rozwoju pisowni hebrajskiej wiemy, że formy w scriptio plena są młodsze od tych pisanych w scriptio defectiva. I choć tradycja masorecka wyraźnie dążyła do ujednolicenia pisowni na podstawie starożytnej Vorlage bez matres lectionis, nie zdołała wyeliminować wszystkich form ze scriptio plena, pochodzących z okresu powygnaniowego. ${ }^{45}$ Podobny proces zauważamy w manuskryptach z Qumran, gdzie kopiści początkowo starają się iść za starszą ortografią, opartą na scriptio defectiva (która później stanie się punktem odniesienia masoretów), ale w trakcie przepisywania spontanicznie ulegają młodszej ortografii qumrańskiej opartej na scriptio plena. Ta niekonsekwencja rzuca się w oczy w manuskrypcie Izajasza (1QIs $\left.{ }^{a}\right)$, gdzie rozdziały 1-33 są pisane w scriptio defectiva, a od rozdziału 34 dominuje scriptio plena. ${ }^{46}$

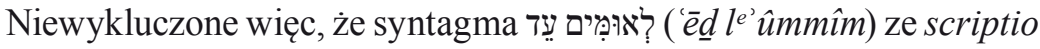

$45, \ldots$ vowel letters were only later introduced into the oldest texts, at first only for final long vowels, and later for medial long vowels. These letters added sporadically and inconsistently. The MT reflects all stages of this practice"; B. K. W a 1 t k e, M. O' C o n n o r, An Introduction to Biblical Hebrew Syntax, s. 24 (zob. też s.17-19, 22-25); ,... the Hebrew Bible which tradition has delivered to us is in reality a palimpsest; underlying the visible text, the varied spelling customs of older ages have been recorded"; F. M. C r o s s, D. N. F r e e d m a n, Early Hebrew Orthography, New Haven 1952, s. 1.

46 E. Y. Ku t c he r, The Language and Linguistic Background of the Isaiah Scroll (1QIs $)^{\mathrm{a}}$, Leiden 1974, s. 433-440,445,448-449,564-566. Zob. trzy manuskrypty qumrańskie, które przekazują Iz 55,4 (bibliografia w przyp. 13):

1QIsa (45,23-24): הנה עד לאומים נתתיהו נגיד ומצוה לאומים

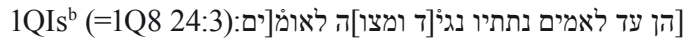

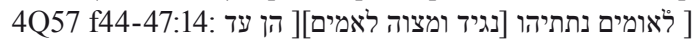


plena w Iz 55,4 wskazuje na późniejszą interpolację i zdradza sposób pisowni, który był bliski redaktorowi powygnaniowemu.

Argumentem mniejszego kalibru jest targum do Iz 55,4, który, choć odzwierciedla strukturę zdania z TM, nic nie mówi o świa-

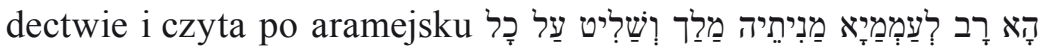

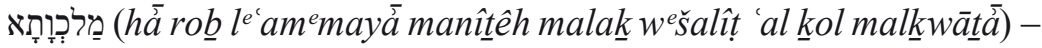
„oto ustanawiam go przywódcą dla narodów, królem i zarządcą nad wszystkimi królestwami”. Być może autor targumu dostrzegł w syn-

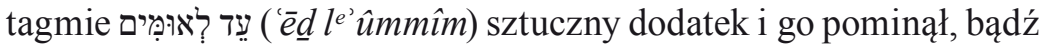
oparł swe tłumaczenie na manuskrypcie, w którym tej syntagmy po prostu nie było.

\section{Iz 55,5 - redakcyjny dodatek mądrościowo-uniwersalistyczny i mesjański}

Partykuła הֵ (hèn) nie pełni tu funkcji deiktycznej (,oto”), jak w w. 4, lecz w konstrukcji: הן + czasownik + waw + nieczasownik + imperfectum przyjmuje znaczenie spójnika zdania rozłączonego warunkowego (,jeśli”) lub czasowego („kiedy”). ${ }^{47}$ Ponadto warunkowe znaczenie partykuły הien (hest arameizmem, ${ }^{48}$ bo w języku hebrajskim normalnym spójnikiem warunkowym jest ('im).

Jeżeli w w. 3 podmiot wypowiadający się zwracał się do adresata w 2 os. 1. mn.. m., w w. 5 zwraca się do niego w 2 os. 1. poj. m. (,wy” $\rightarrow$,ty”). To gwałtowne przejście, jak i arameizująca partykuła הi (hēn), świadczą o działalności redaktora, który w w. 5 ukazał nową misję Izraela-Dawida w kluczu mądrościowym, uniwersalistycznym i mesjańskim. ${ }^{49}$

47 T. O. L a m b d i n, Wprowadzenie do hebrajskiego biblijnego, s. 460.

48 L. K o e h l e r, W. B a u m g a r t n e r, J. J. S t a m m, Wielki stownik hebrajsko-polski i aramejsko-polski Starego Testamentu, s. 239.

49 Najstarsza tradycja Kościoła interpretuje w. 5 chrystologicznie. Pierwszym i jedynym ojcem Kościoła, który ten werset poddał takiej interpretacji był św. Cyryl z Aleksandrii († 444 r.). Według niego, wezwanie pogan zapowiada wezwanie, jakie rozbrzmiewa w Ewangelii Chrystusa, zrodzonego z „Dawidowego nasienia”. Chrystus bowiem w nowym i wiecznym przymierzu wypełnił ,święte i godne 


\section{Klucz mądrościowy}

Klucz mądrościowy jest zawarty w idei nawoływania (קרא - qārā). W w. 3 sam Bóg nawoływał wygnańców do słuchania radosnego orędzia. Teraz w w. 5 ci sami wygnańcy przyjmują na siebie rolę Bożego herolda i w imieniu Boga nawołują ludy (תִ - tiqrā) do szukania Jahwe i do nawrócenia (,Szukajcie Jahwe, gdy pozwala się znaleźć, wzywajcie Go, dopóki jest blisko. Niech bezbożny porzuci swą drogę i człowiek nieprawy swe knowania..." - ww. 6-7). W ww. 5-7 zostaje, więc, rozwinięty motyw uosobionej Mądrości nawołującej na placach i w bramie miasta (Prz 8,1-3nn.: „Czyż Mądrość nie nawołuje

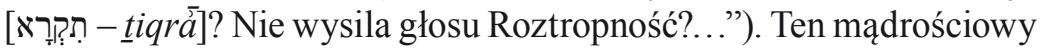
aspekt w oryginalnej perykopie (ww. 1-3.4b) był ledwie dostrzegalny i problematyczny (zob. wyżej). Natomiast w dodanym przez redaktora w. 5 jest widoczny z całą ostrością: głos Boga do Izraela okazuje się nie tyle głosem pocieszenia i „radosnej nowiny”, ile jest głosem powołania, który uwiarygodnia głos Izraela do narodów i nadaje mu autorytet Bożej Mądrości. Na wzór tradycji prorockiej (zob. Jr 1,5b.9-10), Izrael powołany z wysokości Boskiego majestatu (ww. 3-4) ma za zadanie być pośród ludów Mądrością, przemawiającą do ludzkiego rozsądku i sumienia.

\section{Klucz uniwersalistyczny}

Klucz uniwersalistyczny, ściśle związany z motywem mądrościowym, kryje się w paralelizmie „ludy, których nie znasz” - „ludy, które cię nie znająa". Ten paralelizm poetycko opisuje miejsce, skąd Izrael-Mądrość nawołuje. W tradycji sapiencjalnej uosobiona Mądrość

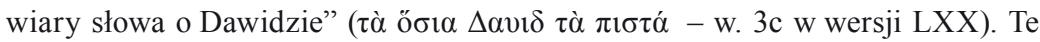
słowa - mówi Cyryl - są ,święte”, bo dzięki mocy usprawiedliwiającej Chrystusa ci, którzy je przyjmują w wierze, stają się doskonali. Zostają przez Chrystusa wezwani z ciemności, uznając Go za Boga; „,biegną” do Niego, bo w Jego ludzkim uwielbionym ciele, widzą swą nadzieję i narzędzie zbawienia; zob. Ś w. C y r y 1 z A l e k s a n d r i i, Komentarz do Izajasza, V, 2 (55,1-5), w: J.-P. M i g n e (red.),

Patrologia cursus completus. Series Graeca, t. 70, kol. 1221-1225. 
zabiera głos wszędzie tam, gdzie są ludzie: na szczytach pagórków i wyżyn, na rozstaju dróg i przede wszystkim u bram miasta. Brama miasta była miejscem konwergencji dróg, które do albo z tegoż miasta prowadziły. Była obowiązkowym miejscem, przez które wszyscy musieli przejść, jeśli chcieli wejść do miasta lub się z niego wydostać. Brama miała też ważne znaczenie społeczne, bo była miejscem zawierania transakcji handlowych, miejscem sądów, wymiany ludzkich opinii i sporów. Stojąc w bramie miasta, Mądrość kieruje swe słowo do różnobarwnego tłumu przypadkowych ludzi, o których wie niewiele. Wydaje się, że tak naprawdę nie wie, do kogo mówi. Ale ona tam właśnie jest dla nich, choć nie do końca zdaje sobie sprawę, czy są zainteresowani jej mową i czy w ogóle jej potrzebują. ${ }^{50}$

Na tle Bliskiego Wschodu, w szczególności Egiptu i Mezopotamii, gdzie mądrość była zarezerwowana dla ludzi z aparatu władzy i była domeną urzędników królewskich i kapłanów, uosobiona Mądrość biblijna nie była elitarna. Nie miała względu na osoby, na ich status społeczny, zawód, płeć, przynależność etniczną. Miała charakter egalitarny i uniwersalistyczny.

Tak oto Izrael w Iz 55,5 staje się bramą ludzkości, w której mieszka Mądrość Jahwe i niestrudzenie nawołuje. Odpowiada do przekonaniu autorów okresu powygnaniowego: ,[Bóg] zbadał wszystkie drogi mądrości i dał ją słudze swemu, Jakubowi, i Izraelowi, umiłowanemu synowi. Potem ukazała się ona na ziemi i zaczęła przebywać wśród ludzi” (Ba 3,37-38: zob. też Syr 24,8; Mdr 9,10).

\section{Klucz mesjański}

Klucz mesjański jest zawarty w ww. 6-7, które wraz z w. 5 stanowią redakcyjny dodatek, opisujący powołanie i mądrościową apoteozę Izraela.

Przymiotnik קָ (qẫốb - „bliski”) w w. 6 sugeruje, że Bóg, powołując Izraela, zbliżył się do człowieka. Wyszedł niejako ze swej świętości, rozumianej jako oddzielenie, żeby się do człowieka zniżyć.

50 M. G i 1 b e r t, La sapienza del cielo, Torino 2005, s. 40. 
Jest to typowy rys czasów mesjańskich - bliskość Boga z człowiekiem i gwałtowne wdarcie się świętości Boga w codzienność i życie ludzi co nieprzypadkowo rzuca się w oczy w pierwszych słowach działalno-

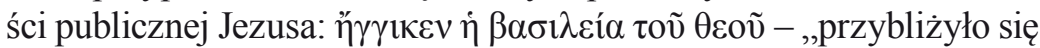
królestwo Boże" (Mk 1,15; zob. też Ml 3,5). Izrael zostaje powołany, aby być Mądrością mesjańską, która „w Jakubie rozbiła swój namiot i w Izraelu objęła dziedzictwo" (Syr 24,8b). A zatem jej zadaniem jest ogłosić narodom bliskość Boga i wezwać je do nawrócenia.

Obraz sądu w w. 7, kolejna cecha tekstów mesjańskich (zob. Ml 3,5; 1QS 9,10-11), jest pośrednio obecny w uwarunkowaniu przebaczenia od pozytywnej odpowiedzi na wezwanie do nawrócenia. Jeśliby ta odpowiedź była negatywna, narody nie otrzymają przebaczenia. Radosny i optymistyczny ton teologii Deuteroizajasza udzielił się redaktorowi, tak że przemilczał los bezbożników odrzucających głos Izraela. Mimo to z perspektywy wygnańców milczenie w tej kwestii, skutecznie wpływało na ich wyobraźnię uformowaną przez proroctwo przedwygnaniowe, głoszące nadciągający sąd i karę. Budząc w nich wewnętrzny niepokój o to, jak poważne mogą być konsekwencje takiego odrzucenia, skłaniało do trwania przy Bogu i zintensyfikowania wysiłków na rzecz nawrócenia narodów.

\section{Wnioski z analizy egzegetycznej}

Wnioski analizy egzegetycznej rzutują na tłumaczenie, strukturę tekstu i jego przesłanie. Ponadto pozwalają na zrozumienie różnic, jakie istnieją między perykopą oryginalną i jej redakcyjnym dodatkiem.

\section{Tłumaczenie Iz 55,3-5}

,Nakłońcie swe ucho i tylko Mnie słuchajcie uważnie:

Ocaliliście swe życie, bo chcę zawrzeć z wami wieczne przymierze. Zaiste moja przeogromna miłość okazana niegdyś Dawidowi jest niewyczerpana.

${ }^{4}$ Oto teraz ustanawiam go świadkiem dla narodów jako ich naczelnego prawodawcę. 
${ }^{5}$ I kiedy będziesz nawoływał narody, których nie znasz, narody, które (też) cię nie znają, pospieszą do ciebie przez wzgląd na Świętego Izraela, który cię wywyższył".

Struktura w kontekście perykopy Iz 55,1-7 i jej retoryczna wymowa

Struktura retoryczna omawianego fragmentu, która musi uwzględnić całą perykopę Iz 55,1-7, ${ }^{51}$ przedstawia się następująco:

A. W e z w a n i e B o g a (do Izraela):...Nakłońcie swe ucho i tylko mnie uważnie słuchajcie (w. 1-3a) $)^{52}$

B. Motyw ują c a za c h ę t a: Ocaliliście swe życie/przeogromna jest miłość Boga do Dawida (w. 3bac)

C. C e 1: zawarcie wiecznego przymierza z Izraelem (w. 3b $\beta$ )

D. P o w o ł a n i e: Izrael - Boży prawodawca narodów (w. 4b)

D’. P o w o ła n i e: Izrael - Boży świadek i mesjańska Mądrość wśród narodów (ww. 4a.5)

A'. We z w a n i e I zra el a (do narodów): Szukajcie Jahwe... wzywajcie Go... (w. 6aa.6ba.) $)^{53}$

B'. M o t y w u j ą c a $\mathrm{z}$ a c h ę t a: Jahwe pozwala się znaleźć i jest blisko (w. $6 \mathrm{a} \beta .6 \mathrm{~b} \beta$ )

C'. C e l: nawrócenie i przebaczenie dla narodów (w. 7)

Dwa bloki (A-C) i (A'-C') stoją naprzeciw siebie w pozycji inkluzyjnej i centralnie wyogniskowują powołanie Izraela w stosunku do narodów (D-D'). To powołanie jest ukazane w dwóch aspektach: legislacyjnym i mądrościowym.

Ponadto, oba bloki mają odpowiednio dwie pary protagonistów: Bóg - Izrael (A-C) i Izrael - narody (A'-C'), co dodatkowo wzmacnia

51 Od w. 8 ponownie na scenę wchodzi Bóg ze swoją mową. Wersety 8-11 kontynuują mowę Boga, przerwaną w w. 4.

52 Inaczej K. B a lt z e r, Deutero-Isaiah, s. 468, który widzi w ww. 1-3a wezwanie ze strony Syjonu/Jerozolimy.

53 J. D. W. W a t t s, Isaiah 34-66, Waco 2005, s. 818, widzi tu mowę skierowaną do perskiego króla Dariusza i przesuwa datację całego fragmentu na V w. przed Chr. 
ich pozycję inkluzyjną, ale jednocześnie tworzy retoryczne napięcie. Na skrzyżowaniu obu bloków rodzi się bowiem pytanie: W jakiej relacji do siebie stoją związek Boga z Izraelem i związek Izraela z narodami? Co łączy te dwa związki? Centralna pozycja, w której znajduje się Izrael (D-D'), zdaje się podpowiadać, że pełni on rolę pośrednika między Bogiem i narodami. Jego powołanie w kontekście wiecznego przymierza jest w całości ukierunkowane na urzeczywistnienie głównego celu, jakim jest przebaczenie narodom (w. 7).

Dynamika retoryczna perykopy ukazuje również pewną ciekawą zmianę w teologicznej koncepcji przymierza. O ile przymierze było bilateralną relacją Boga z Izraelem i istotą Bożego wybraństwa na tle innych narodów, o tyle tutaj owa wyjątkowa relacja - owszem zachowuje swoją ważność, ale przestaje być celem samym w sobie. Celem staje się pozytywna odpowiedź, jakiej Izrael udzieli Bogu, żeby otworzyć narodom drogę do przebaczenia i w dalszej perspektywie - choć nie zostaje to powiedziane explicite - włączyć je w dynamikę wiecznego przymierza. Jeśli Izrael wiernie wypełni swe powołanie, pomoże w realizacji Bożego planu zbawienia.

Motywująca zachęta w obu blokach (B-B') pełni rolę przynaglenia, w przypadku Izraela, do wejścia w dynamikę nowego przymierza, w przypadku narodów, do nawrócenia.

Warto też zauważyć, że jeżeli ww. 4a.5-7 są redakcyjnym dodatkiem, zostają włączone w klinem w oryginalną perykopę Iz 55,1-3.4b.8-11 (cezura redakcyjna przechodziłaby między D i D'). I rzeczywiście, mowa Boga, przerwana w w. 4 znajduje swą kontynuację w ww. 8-11 (zob. 1 os. 1. poj.). Z tej perspektywy w ww. 8-11 Bóg ukazałby powód, dla którego w kontekście wiecznego przymierza powołał Dawida-Izraela do zupełnie nowej misji na rzecz narodów.

Przesłanie Iz 55,3-5 jako odpowiedź na wewnętrzne rozterki wygnańców

Bóg, niczym uosobiona Mądrość, stoi przy bramie miasta i wzywa zafrasowanych codziennością bytu wygnańców, aby oderwali się od spraw przyziemnych i spojrzeli na sytuację z perspektywy Boga, 
z wysokości Jego Boskiej transcendencji. Chce im przekazać dobrą nowinę - „ewangelię” o ocaleniu z opresji i o ich namaszczeniu na świadków i prawodawców narodów. Ich życie nie było, więc, życiem przypadkowym. Ich trwanie na obczyźnie nie było mimowolnym zejściem na kompromis z otaczającą rzeczywistością. Było darem Boga, znakiem Jego nieprzerwanej miłości i podstawą do nawiązania nowej relacji, która będzie trwała wieczna. ${ }^{54}$

\section{Wewnętrzne rozterki wygnańców}

To optymistyczne przesłanie wychodzi naprzeciw frustracji, która zagościła w sercach wygnańców i odcisnęła swe piętno w ich psychice (I) i w religijnym nastawieniu do Jahwe (II).

I. Z jednej strony, tęsknota za Jerozolimą zaczęła słabnąć do tego stopnia, że musieli sztucznie ją podtrzymywać przekleństwami skierowanymi przeciw sobie (Ps 137,1-6: „....Jeruzalem, jeśli zapomnę o tobie, niech uschnie moja prawica! Niech język mi przyschnie do podniebienia...”). Z drugiej strony, świadomość niemocy wobec zaistniałej sytuacji politycznej budziła w nich pragnienie zemsty i rewanżu nie tylko na Babilończykach, ale również na Edomie, bratnim narodzie, który wzbogacił się na ich krzywdzie i bezdusznie wykorzystał moment, gdy - idąc na wygnanie - musieli zostawić swoje domostwa (Ps 137,7-9: „Przypomnij, Panie, synom Edomu dzień Jeruzalem, kiedy oni mówili: Burzcie, burzcie - aż do samych fundamentów! Córo Babilonu, niszczycielko, szczęśliwy, kto ci odpłaci za zło, jakie nam wyrządziłaś!...”). Tę frustrację pogłębiały roszczenia ziomków, którzy pozostali w ojczyźnie i zaczęli podważać ich prawo własności do zostawionych w Judzie majątków (Ez 11,15; 33,24). Sami wygnańcy, wywodzący swe pochodzenie ze starej arystokracji judzkiej, nadal czuli paraliżujący ciężar odpowiedzialności za katastrofę narodową

54 G. v o n R a d, Teologia dell'Antico Testamento, t. 2, Brescia 1974, s. 281-284; J. B 1 e n k i n s o p p, A Jewish Sect of the Persian Period, CBQ 52/1990, s. 39-49; $\mathrm{H}$. T a d m o r, The Babylonian Exile and the Restoration, w: H. B e n - S a s s o n (red.), A History of the Jewish People, Cambridge 1976, s. 168. 
z 587 r. (Ez 33,10). Z kolei potomkowie przeciwników politycznych ich ojców i dziadów nie dawali im o tym zapomnieć i nadal wystawiali rachunek krzywd i niesprawiedliwości (Ez 18,2.19). Ta frustracja musiała szybko narastać, skoro już Ezechiel i jego uczniowie podjęli szeroko zakrojoną ,akcję duszpasterską", żeby ocalić w wygnańcach poczucie własnej godności, przepowiadając restytucję utraconych praw własności i przywilejów pierwszeństwa (Ez 11,16-21). Również problem odpowiedzialności zbiorowej za grzechy ojców odbił się szerokim echem w przepowiadaniu Ezechiela (Ez 18).

II. Z upływem czasu, im bardziej płonne stawały się nadzieje na rychły powrót do ojczyzny, tym bardziej dawały znać o sobie rozterki natury religijnej. W odczuciu wygnańców Jahwe przez okres jednego pokolenia przestał interesować się ich losem. Nie uznawał ich prawa do życia (Iz 40,27) i ich opuścił (Iz 50,1). Kiedy więc Judejczycy widzieli babilońskie bóstwa niesione triumfalnie w okazałych procesjach (Iz 46,1-2), kiedy patrzyli na ich wizerunki pośród wiwatującego tłumu, zdawało się, że Jahwe brakuje woli i siły do ukazania swej władzy nad światem i do wybawienia swój naród z niewoli (Iz 50,2). Wydawało się, że jest On Bogiem słabym. I choć w życiu prywatnym wygnańcy nadal czuli Jego obecność, to w życiu politycznym Jahwe wydawał się wycofany do tego stopnia, że niczego dobrego nie mogli się już po Nim spodziewać. ${ }^{55}$ Wielu spośród wygnańców musiało dojść do przekonania, że należy porzucić dawne nadzieje i zająć się sobą: rodzinnym szczęściem, pomnażaniem majątku i robieniem kariery w strukturze społecznej, administracyjnej i wojskowej państwa babilońskiego. A takie możliwości stały przecież otworem.

W tak nakreślonej pokrótce sytuacji przesłanie Deuteroizajasza, w tym interesująca nas perykopa Iz 55,3-5, musiały być odebrane jako pozytywny przełom, elektryzujący wstrząs w psychice wygnańców. ${ }^{56}$

55 O rozczarowaniu i lamentacjach tamtego okresu w kontekście 2Sm 7,8-16; $1 \mathrm{Krl}$ 8,23-26; 2Sm 23,5; Ps 89 zob. C. We s t e r m a n n, Isaia 40-66, s. 341.

${ }_{56}$ Szersza panorama tamtego okresu zob. M. Li ve r a n i, Oltre la Bibbia, s. $223-234$. 
Dawidowa monarchia w Iz 55,3-5 jako przeciwwaga dla mesjańskiej roli Cyrusa

Jedyna wzmianka o Dawidzie, jaka pojawia się w u Deuteroizajasza (Iz 40-55), jest nawiązaniem do teologii monarchii przedwygnaniowej i stanowi pożądaną korektę i cenną przeciwwagę dla zbyt śmiałej wizji teologicznej, która na fali wzmożonego entuzjazmu i rozbudzonych nadziei wokół osoby Cyrusa, prowadziła do paradoksalnych i szokujących wniosków: Cyrus, poganin, nieznający Jahwe, zostaje ogłoszony mesjaszem (Iz 44,28; 45,1.4-5.13; 48,15; zob. też $41,2.25 ; 46,11)$. I choć początkowo ta teologiczna interpretacja historycznych wydarzeń z lat 550-539 była zrozumiała i skuteczna, żeby wyrwać wygnańców z uśpienia, bardzo szybko spotkała się z wrogością nie tylko ich samych, ale również napotkała opór w samym środowisku prorockim, z którego wyszła. Czyż Jahwe mógł powołać z dalekiej Persji obcego władcę, króla, który Go nie znał (Iz 45,5), aby zainaugurował mesjańską erę powszechnego zbawienia? Takie przesłanie brzmiało niewiarygodnie. Było paradoksalne. I, co więcej, nie znajdowało potwierdzenia w oficjalnej tradycji teologicznej. Owszem cudzoziemcy mogli być w ręku Boga narzędziem kary (Iz 10,5-12; Jr 27,6), ale namaszczenie na mesjasza obcego króla wykraczało poza religijną wyobraźnię Żydów, bo nie znajdowało potwierdzenia we wcześniejszej tradycji. A przecież zgodnie z nią tylko potomek Dawida mógł pełnić tę funkcję.

Wydaje się, że przesłanie Deuteroizajasza przynajmniej w pierwszym okresie działalności tej grupy prorockiej musiało jawić się jako teologicznie niepoprawne, gorszące, a nawet bluźniercze. $Z$ łatwością możemy sobie wyobrazić negatywną i ostrą reakcję ze strony kręgów żydowskich tradycjonalistów i nacjonalistów, z których wywodzili się też prorocy stojący za Deuteroizajaszem. W obliczu takiej reakcji musieli na nowo przemyśleć przesłanki swego proroctwa i dostosować je do przedwygnaniowej teologii jahwistycznej, żeby mogła się bronić i była wiarygodna w uszach odbiorców.

Cyrusowe mesjaństwo zostało więc włączone w ramy szerszej teologii apologetycznej, która doprowadziła wiarę we wszechmoc 
Boga do ekstremalnych wniosków (Bóg stwarza nie tylko światło, ale i ciemność; Bóg nie tylko daje zbawienie, ale i zsyła nieszczęście - Iz 45,7 wbrew Rdz 1,2) i ukazała, że choć Jahwe konsekwentnie realizuje to, co zapowiedział, to jednak zbawienie, jakiego dokonuje, niesie z sobą potężny ładunek nowości i zaskoczenia (Iz 42,9; 43,18-19; 48,6b-8). Innym ważnym elementem tej apologii jest afirmacja absolutnego monoteizmu. Ta kwestia często jest poruszana podczas fikcyjnych procesów, które Bóg odbywa z narodami lub z ich bóstwami w swej niebiańskiej siedzibie (Iz 41,1-5.21-29; 43,8-13; 44,6-8; 45,20-25). W tym apologetycznym kontekście należy też umiejscowić odniesienie do monarchii Dawidowej ${ }^{57}$ i do roli, jaką Deuteroizajasz w Iz 55,3-5 wyznaczył Izraelowi względem narodów.

\section{Mesjaństwo Dawida w Iz 55,3-5 na tle wcześniejszej tradycji biblijnej}

Na tle wcześniejszej tradycji biblijnej mesjaństwo Dawida w Iz 55,3-5 zostaje zobrazowane za pomocą starych pojęć, którym nadaje się nowe znaczenie. Wpisuje się to w naszkicowany powyżej trend apologetyczny Deuteroizajasza, który, pogłębiając fenomenologię Bożego działania w świecie, nieprzystającego do dawnych teologicznych kategorii i religijnych przekonań żydowskich wygnańców, bronił wiarygodności swego przesłania. Samo imię Dawida,

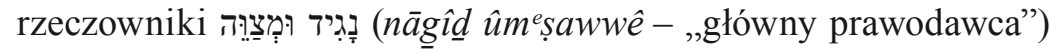
opisujące jego status pośród narodów, odniesienie do treści „wiecznego przymierza", wyrażonej w zintensyfikowanej liczbie mnogiej

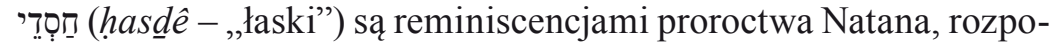
znawalnymi dla każdego Żyda. Jednak w treści i strukturze perykopy (Iz 55,1-7), do której należą omawiane wersety, jak i w szerszym kontekście Księgi Deuteroizajasza (Iz 40-55), rozbrzmiewa zupełnie nowe orędzie o zbawieniu wraz z kiełkującą samoświadomością Izraela co do swej roli w świecie.

57 Na temat teologii monarchii Dawidowej w historii biblijnej zob. G. v o n R a d, Teologia dell'Antico Testamento, t. 1, s. 352-363. 


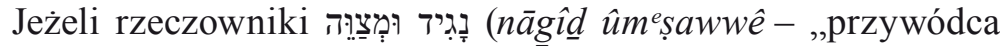
i rozkazodawca") we wcześniejszej tradycji biblijnej były traktowane oddzielnie i miały wydźwięk polityczny, ${ }^{58}$ podkreślając szeroki zakres władzy Dawida nad Izraelem $(2 \mathrm{Sm} 7,8)$, teraz tworzą hendia$d y s$ w wyjaśniającej apozycji do rzeczownika עِ ('êd - ,świadek”). Nie wyrażają więc, istoty mesjaństwa (tą istotą jest świadectwo i nawoływanie narodów), lecz razem obrazują sposób jego konkretyzacji w nadaniu narodom prawa. Dawid jako Boży świadek tylko wtedy wypełni swą mesjańską rolę, jeśli zajmie poczesne miejsce głównego prawodawcy narodów i będzie je wzywał do nawrócenia. Ten rodzaj przywództwa nie otwiera Dawidowi drogi do jakiejś politycznej czy królewskiej władzy nad narodami (Deuteroizajasz

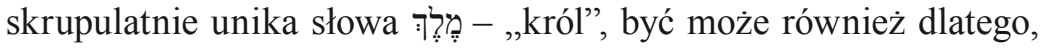
by nie tworzyć napięć z królewską władzą Persów), lecz nadaje mu status autorytetu moralnego i religijnego. Jeśli władza polityczna ucieka się do wywierania przymusu, również za pomocą środków militarnych, moralna i duchowa władza Dawida ma charakter ireniczny. Apeluje do sumienia i nawołuje do nawrócenia, przekonując jedynie siłą swego świadectwa i wiarygodności. Dlatego odpowiedź ze strony słuchaczy pozostaje kwestią ich wolnej woli i wewnętrznego przekonania.

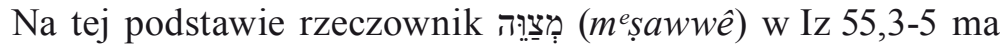
swój pierwowzór w funkcji Mojżesza, pierwszego מִ par excellence. ${ }^{59}$ Dlatego nie oznacza „rozkazodawcy” w sensie

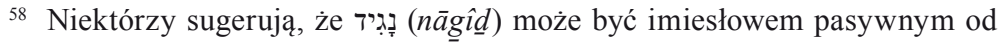
czasownika נגד i jako passivum divinum oznacza ,wskazany przez Jahwe”, ,wyznaczony przez Jahwe"; A. A 1 t, The Formation of Israelite State in Palestine, w: t e n ż e, Essays on the Old Testament History and Religion, Garden City 1967, s. 195, przyp. 5. Inni z kolei, widzą tu formę czasownikową Hifil czasownika נגד, która oznaczałaby ,proklamację”, „głoszenie”, „,bycie piewcą” i łączyłoby funkcję Dawida jako נָּגִ (nāgîl ) z jego psalmami, gdzie opiewał dobroć Boga i Jego łaskę; zob. K. B a 1 t z e r, Deutero-Isaiah, s. 472, przyp. 49.

${ }_{59}$ Takie rozumienie czasownika צוה też w psalmach; zob. np. H.-J. K r a u s, Psalms 1-59, Minneapolis 1989, s. 267-276. 
polityczno-militarnym, ${ }^{60}$ lecz w zgodzie z teologią Deuteroizajasza oznacza „prawodawcę”, czyli tego, który da narodom prawo („,On przyniesie narodom prawo" - Iz 42,1) i rozszerzy normatywną przestrzeń przymierza synajskiego na całą ludzkość.

Obok Mojżesza, głównego prawodawcy Izraela (w. 4), innym punktem odniesienia dla mesjańskiej roli Dawida jest uosobiona Mądrość (ww. 5-7). W uporczywym nawoływaniu (קרא-qārā: zob. w. 5) daje słyszeć głos Jahwe, Boga miłosiernego, gotowego przebaczyć wszystkim narodom ziemi ich grzech bałwochwalstwa ${ }^{61} \mathrm{~W}$ kontekście perykopy Iz 55,1-7, jak i w odniesieniu do tego, co powiedzie-

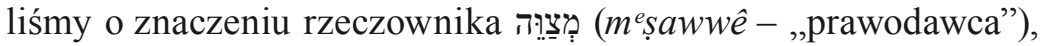
treścią nawoływania jest Tora, Boże prawo. Skoro głównym celem Dawidowego mesjaństwa jest nadać narodom prawo, istotą nawrócenia narodów (również Cyrusa) musi być jego przyjęcie. Tylko wtedy Bóg udzieli im swego przebaczenia (,,... niech bezbożny nawróci się do Pana, a Ten się nad nim zmiłuje...”; w. 7).

Warto zauważyć, że w takim przedstawieniu Dawida dokonuje się demitologizacja biblijnego pojęcia mądrości. Dawid jest jednocześnie i mesjaszem i ucieleśnieniem Tory. Jest mesjańską Mądrością, która nabiera rysów żywej Tory pośród narodów. Demitologizacja biblijnej mądrości jest stałą cechą najmłodszych pismach Starego Testamentu i niewykluczone, że początek tego procesu wyznaczył właśnie Deuteroizajasz (zob. Ba 4,1: „Tą mądrością jest księga przykazań Boga i Prawo trwające na wieki...”; Syr 24,23: „Tym wszystkim [mądrością] jest księga przymierza Boga Najwyższego, Prawo, które dał nam Mojżesz...").

Ponadto Dawid jako mesjańska Mądrość wyraża całą wspólnotę judejskich wygnańców, do której zostaje skierowane wezwanie i słowa zachęty. ${ }^{62}$ Ta judejska wspólnota nie waha nazwać się Izraelem, dzie-

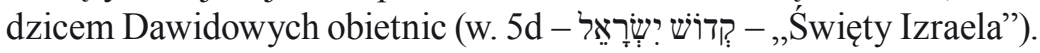

60 Tak sugeruje większość nowożytnych tłumaczeń Biblii.

${ }^{61}$ C. We s t e r m a n n, Isaia 40-66, s. 343, odnosi motyw „nawoływania” do Ps 18,44 .

${ }^{62}$ O tym świadczy użycie 2 os. 1. m. w w. 3. 
W postaci Dawida Deuteroizajasz widzi więc punkt konwergencji między przedwygnaniową tradycją teologiczną i nową, religijno-narodową i wspólnotową samoświadomością Izraela, która pozwala na odnalezienie się w zmienionej sytuacji i przygotowuje grunt pod trudne współżycie z narodami.

Dawid-Izrael jako mesjańska Mądrość pośród narodów świata nawołuje do przyjęcia Bożego prawa i w ten sposób daje świadectwo o Bogu. Czego to świadectwo konkretnie dotyczy? Kontekst bliższy i dalszy sugeruje, że dotyczy ono monoteizmu (I) i przebaczenia (II).

I. W kontekście Księgi Deuteroizajasza można powiedzieć, że to świadectwo dotyczy absolutnego monoteizmu (Iz 43,9-10.12; 44,8-9) - Jahwe jest Jedynym Bogiem, jedynym Stwórcą i Zbawcą człowieka. Współgrałoby to z pojęciem Tory, która zasadza się na pierwszym przykazaniu Dekalogu: „Nie będziesz miał bogów cudzych przede Mną" (Wj 20,3.23; Pwt 5,7; 6,14; 8,19). Przyjmując Torę, ludy odrzucają bałwochwalstwo i wyznają wiarę w Jahwe, którego pierwszym świadkiem jest Dawid. Taka interpretacja jest jak najbardziej możliwa. ${ }^{63}$

II. Jednak patrząc na strukturę retoryczną perykopy Iz 55,1-7 (zob. wyżej), wydaje się, że skoro ostatecznym celem mesjańskiej misji Dawida jest nawrócenie ludów i doświadczenie Bożej miłości i przebaczenia, to również jego świadectwo, żeby było wiarygodne, powinno polegać na doświadczeniu miłości Boga i dążyć do tego samego celu. Intencjonalność Dawidowego świadectwa powinna pokrywać się z intencjonalnością jego mesjanizmu. Dawid jest tym, który „ocalił swe życie” i dostał nową szansę od Boga (Iz 55,3bc). Ale jest również tym, który „odebrał z ręki Pana karę w dwójnasób i jego grzech został odpuszczony (רצה - Iz 40,2)". W doświadczeniu miłosierdzia Boga staje się świadkiem Jego zmiłowania i przebaczenia.

63 Tak uważa K. B a lt z e r, Deutero-Isaiah, s. 471. Z kolei F. D e 1 i t z s c h, Biblical Commentary on the Prophecies of Isaiah, Grand Rapids 1954, t. 2, s. 355-357 łączy świadectwo Dawida z psalmami, które w tradycji biblijnej były mu przypisywane. 
I nie powinien tego przebaczenia negować nikomu, nawet Cyrusowi, jeśli ten się do Boga nawróci.

Konkludując, należy stwierdzić, że świadectwo Dawida jest jednocześnie świadectwem wiary monoteistycznej, wyrażającym się w przyjęciu i przestrzeganiu Tory oraz świadectwem o sile Bożego miłosierdzia. Innymi słowy, jest to mesjańskie świadectwo o Bogu Jedynym i Miłosiernym.

\section{Redakcyjny dodatek i jego interpretacja}

Analiza egzegetyczna ${ }^{64}$ wskazuje na działalność redaktora, który do oryginalnych wersetów (Iz 55,3.4b) dołączył aktualizujące rozszerzenie (Iz 55,4a.5). Poniższa tabelka poglądowo konfrontuje obie części:

\begin{tabular}{|c|c|}
\hline Wersety oryginalne - Iz 55,3.4b & $\begin{array}{l}\text { Wersety dodane przez } \\
\text { redaktora - Iz 55,4a.5 }\end{array}$ \\
\hline $\begin{array}{l}\text { „Nakłońcie swe ucho i tylko } \\
\text { Mnie słuchajcie uważnie: } \\
\text { Ocaliliście swe życie, bo chcę } \\
\text { zawrzeć z wami wieczne } \\
\text { przymierze. Zaiste moja } \\
\text { przeogromna miłość oka- } \\
\text { zana niegdyś Dawidowi jest } \\
\text { niewyczerpana. } \\
\text { 4bOto teraz ustanawiam go } \\
\text { naczelnym prawodawcą dla } \\
\text { narodów (przywódcą i rozka- } \\
\text { zodawcą dla narodów?)”. }\end{array}$ & $\begin{array}{l}{ }^{4 a} \text { Oto teraz ustanawiam (cię) } \\
\text { świadkiem dla narodów. } \\
{ }^{5} \text { I kiedy będziesz nawoływał } \\
\text { narody, których nie znasz, } \\
\text { narody, które (też) cię nie } \\
\text { znają, pospieszą do ciebie przez } \\
\text { wzgląd na Świętego Izraela, } \\
\text { który cię wywyższył”. }\end{array}$ \\
\hline
\end{tabular}

Wytłuszczenie wskazuje na główny problem redaktora

Uwaga redaktora skupia się na hendiadys (nāgî $\hat{u} m^{e} s a w w e \hat{e}$ - w. 4b), która w tradycyjnej teologii królewskiej oznaczała

${ }^{64}$ Zob. wyżej. 
„przywódcę i rozkazodawcę” i miała wydźwięk nacjonalistyczny. Jednak redaktor, dodając ww. 4b.5, zinterpretował ją w kluczu świadectwa i uosobionej Mądrości, która nawołuje narody do nawrócenia i przyjęcia Bożego prawa. Wprowadzona korekta sprawia, że hendiadys traci swoją wiodącą pozycję w strukturze syntaktycznej wersetu i przyjmuje funkcję apozycji wyjaśniającej w stosunku do

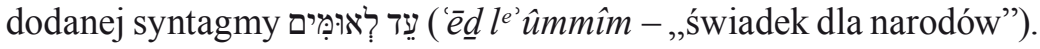
Tym samym akcent przesuwa się na dawanie świadectwa (w. 4) i mądrościowe pouczanie narodów (w. 5). A zatem w intencji redaktora należało unikać takiej interpretacji nowego przymierza i mesjańskiej misji Dawida, która uderzałaby w tony polityczno-nacjonalistyczne i militarne. Redaktor chce niejako powiedzieć, że postrzeganie się jako przywódcy pretendującego do tronu i do militarnej dominacji mogłoby w niedalekiej przyszłości doprowadzić do konfliktu z Persami. Z kolei niepotrzebne rozbudzanie nastrojów nacjonalistycznych mogło prowadzić do rewanżyzmu i chęci odegrania się za poniesione krzywdy i materialne straty, co bez wątpienia zaogniłoby niełatwą relację z krajami sąsiednimi, a nawet mogło rozbudzić konflikty na tle etnicznym z cudzoziemcami mieszkającymi w granicach Judy. $\mathrm{W}$ ten sposób redaktor dawał wyraz teologicznemu pacyfizmowi, który w zniszczonym kraju był jedyną możliwą drogą, prowadzącą do szybkiej odbudowy zrębów państwowości i systemu religijnego, bez uszczerbku na narodowej dumie i tradycji. Podkreślając ich doświadczenie miłosierdzia, które było najstarszą warstwą przepowiadania Deuteroizajasza (Iz 44,22), redaktor stawiał Judejczyków w roli świadka Bożego przebaczenia. Czyż jako posłańcy zmiłowania mogli w swych sercach nadal żywić urazę bądź pragnienie zemsty?

Warto też zwrócić uwagę na to, że dodatek redakcyjny przesuwa ciężar teologii Deuteroizajasza z pozycji judeocentrycznej (pozycja prominentna: Dawid, sprzymierzeniec Boga, wódz i rozkazodawca narodów) na pozycje etnocentryczne (pozycja służebna: Dawid prawodawca nawołujący narody do nawrócenia i przyjęcia Bożego prawa).

Kim był redaktor? Mógł przynależeć do nurtu prorockiego Deuteroizajasza i dodał swe mądrościowe rozszerzenie jeszcze przed końcem wygnania. Wskazuje na to dbałość o symetrię w retorycznej 
strukturze perykopy Iz 55,1-7 (zob. wyżej), jak i teologiczna wrażliwość w wykorzystaniu konkretnych obrazów i pojęć, cechy charakterystyczne tej szkoły prorockiej. Jeśli jednak dodał swoją korektę po wygnaniu, mógł być być przedstawicielem świeckiej arystokracji, przywiązanej do etyki ksiąg mądrościowych Starego Testamentu, otwartej na świat, cudzoziemców i inne kultury (zob. Księga Hioba, Księga Jonasza). Jednak utożsamienie Mądrości mesjańskiej z Torą było najprawdopodobniej ukłonem w kierunku deuteronomistów, którzy dbali z jednej strony o pokojowe współżycie z perską władzą i cudzoziemcami, z drugiej o zbudowanie jak najszerszego kompromisu społecznego wokół kodeksu praw, które za aprobatą Persów miały znaleźć się w Pentateuchu. Ważnym czynnikiem w zdefiniowaniu pochodzenia redakcyjnego dodatku jest więc idea pacyfizmu i połączenie wątku mądrościowego z legislacyjnym, która zbliża to przesłanie do świeckich kręgów z powygnaniowej elity rządzącej, identyfikującej się bardziej z nurtem deuteronomistycznym. ${ }^{65}$

\section{Teologia Dawidowego świadectwa w Iz 55,3-5}

Nie jest łatwo opisać teologię świadectwa na podstawie tak krótkiego fragmentu. Można jedynie zarysować jej podstawowe cechy charakterystyczne. A są one związane z przebaczeniem, przymierzem i mesjańską Mądrością.

\section{Źródło Dawidowego świadectwa}

Dawidowe świadectwo zasadza się na doświadczeniu niezmierzonej miłości Jahwe (Iz 55,3c), który przebacza (Iz 40,2), wybawia z opresji (Iz 55,ba) i dochowuje wierności dawnym obietnicom. Choć w przeszłości miłość Boga została zraniona niewiernością Izraela, to jednak na horyzoncie wydarzeń rozgrywających się na scenie międzynarodowej prorok dostrzega rysującą się perspektywę nowego początku, którą

${ }^{65}$ W. B r u e g ge m a n n, Is 55 and Deuteronomic Theology, ZAW 80/1968, s. 191-203. 
odczytuje jednoznacznie jako znak Bożego przebaczenia i propozycję nowego przymierza. To przymierze, wyznaczając nową przestrzeń wspólnoty życia dla Boga i Izraela w zmienionej sytuacji historycznej, jest kontynuacją długiej historii, mającej swój początek w powołaniu Abrahama (Iz 41,8: „Ty, zaś, Izraelu, mój sługo, Jakubie, którego wybrałem sobie, potomstwo Abrahama, mego przyjaciela! Ty, którego pochwyciłem na krańcach ziemi, powołałem cię z jej najdalszych stron i rzekłem ci: «Sługą moim jesteś, wybrałem cię...»”; 51,2: „Wejrzyjcie na Abrahama, waszego ojca /.../ bo powołałem jego jednego...”). Kamieniem milowym tej historii jest proroctwo Natana, w którym Jahwe oficjalnie zaakceptował monarchię izraelską i obiecał królowi Dawidowi nieprzerwane panowanie jego dynastii (2Sm 7).

W Iz 55,3-5 Jahwe, ukazując siłę swego miłosierdzia (חֶֶ - hesed w. 3c), pragnie, by wygnańcy odczytali swe życie na obczyźnie i otwierającą się przed nimi świetlną przyszłość, w świetle Bożej wierności i dawnych obietnic, których są depozytariuszami i naocznymi świadkami ich wypełnienia.

Dawidowe świadectwo jako odpowiedź na dar nowego przymierza

Ustanowienie Izraela na świadka dokonuje się w kontekście wiecznego przymierza (w. 3b $\beta .4 \mathrm{a}$ ), które wyznacza nową kartę w historii zbawienia. Nie chodzi więc o świadectwo akcydentalne czy mimowolne. Jest ono przez Boga zamierzone. Bóg chce, żeby jego sługa Izrael doświadczył tego samego klimatu bezpieczeństwa i zaufania, jaki charakteryzował okres patriarchów, a w szczególności chwalebny okres panowania Dawida. Innymi słowy, żeby doświadczył tej odwiecznej miłości, którą Jahwe zawsze otaczał swój naród. W ustanowieniu na świadka widzimy więc zaproszenie skierowane do Izraela, żeby namacalnie niejako dotknął i zasmakował ${ }^{66}$ nowej jakości życia

${ }^{66}$ Nieprzypadkowo Iz 55,1-2 nawiązuje do wybornej uczty; zob. biesiadny kontekst zawarcia przymierza w Wj 24,11b. J. F. C r a g h a n, Księga Wyjścia, w: W. R. Far m e r (red.), W. Ch ro s t o w s k i (red. nauk. wyd. pol.), Międzynarodowy komentarz do Pisma Świętego, Warszawa 2001, s. 348-349; W. K o p e ć, 
przeżywanego w bezpośredniej bliskości Boga, na jaką przymierze pozwalało. To całkowicie niezasłużone i nieoczekiwane zaproszenie jest darem, który wymaga ze strony Izraela jasnej i natychmiastowej odpowiedzi.

Odpowiedź polega na złożeniu świadectwa o miłości Boga, który przebacza i pozostaje wierny swemu słowu pomimo ludzkiego grzechu i słabości. Dawidowe świadectwo wpisuje się więc w wewnętrzną dynamikę przymierza synajskiego. Jeżeli w klasycznym ujęciu przymierze synajskie było przestrzenią, w której Bóg okazywał człowiekowi swą חִֶ (hesed - „łaska”, ,miłość”), to człowiek w odpowiedzi na Boży dar musiał ukazać tę samą ח̣̋ (hesed ) - jak w zwierciadle W swym etycznym postępowaniu (zob. np. Kpł 19,2). ${ }^{67}$ Ta ogólna norma (postulat naśladowania Bożej ḥesed ) została skonkretyzowana w prawie Mojżeszowym, przede wszystkim w Dekalogu, który pomagał odwzajemnić Bożą (hese $\underline{\text { d }}$ ) w życiu etycznym. Innymi słowy, przymierze synajskie było moralnością życia, w którym odbijała się moralna świętość Boga. ${ }^{68}$

Porównanie z przymierzem synajskim sugeruje, że kierowanie się w życiu Bożą ḥesed przez posłuszeństwo Dekalogowi odpowiada przez analogię składaniu świadectwa w odnowionym przymierzu w Iz 55,3-5. Czy oznacza to jednak, że przymierze w Iz 55,3-5 jest

Starotestamentalne przymierza zapowiedzia i znakiem, w: Eucharystia sakramentem braterstwa, Wrocław 2002, s. 25-26; A. J a n k o w s k i, Biblijne pojęcie przymierza, w: Biblijna teologia przymierza, Kraków 1997, s. 42.

${ }_{67}$ Podobna dynamika jest w Nowym Przymierzu zawartym we krwi Chry-

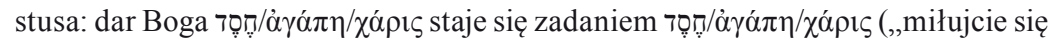
nawzajem tak jak Ja was umiłowałem" - J 15,10.12), które konkretyzuje się w nowym przykazaniu (,p r z y k a z a n i e nowe daję wam”- J 13,34). Chociaż struktura obu przymierzy jest bardzo podobna, istnieje między nimi zasadnicza różnica. W Nowym Przymierzu ową חָ jest Jezus, prawdziwy Bóg i prawdziwy Człowiek. I to On jest istotą chrześcijaństwa, a nie etyka moralnego postępowania, charakteryzująca stare przymierze.

68 Nieco inną perspektywę, która łączy Ps 89 z Iz 55,3-5, przedstawia O. E i s $\mathrm{s}$ f e $1 \mathrm{~d} \mathrm{t}$, The Promises of Grace to David in Isaiah 55,1-5, w: B. W. A n d e r s o n, W. H a r r e 11 s o n (red.), Israel's Prophetic Heritage. Essays in Honor of James Muilenburg, New York 1962, s. 196-207. 
jakościowo innym przymierzem? Otóż nie. Nic nie wskazuje na to, żeby owo przymierze swą treścią różniło się znacząco od przymierza synajskiego z jego Torą. ${ }^{69}$ Jednak wprowadzenie pojęcia „świadectwo" może podpowiadać, że treść przymierza synajskiego nieco się poszerzyła, bądź uległa przeakcentowaniu w kierunku przebaczenia i okazania miłosierdzia grzesznikom. A zatem w odpowiedzi na dar przymierza po wygnaniu babilońskim Żydzi powinni uzewnętrznić Bożą ḥesed nie tylko przez posłuszeństwo Torze, ale i przez wybaczenie narodom - swym ciemiężycielom i prześladowcom w taki sam sposób, jak im „po odebraniu z ręki Pana kary w dwójnasób” zostało przez Boga wybaczone. Doświadczywszy Bożego miłosierdzia, stają się jego piewcami i naśladowcami. Stają się świadkami.

Dawidowe świadectwo jako mesjańska odpowiedzialność za innych

Gotowość do przebaczenia, charakteryzująca odnowione przymierze w Iz 55,3-5, nie jest bezwarunkowa ani naiwna. Miłosierdzie nie oznacza, bowiem, lekceważenia zła czy ślepego tolerowania niesprawiedliwości. Wymaga nawrócenia do Boga i uznania Go za Jedynego Stwórcę i Zbawcę człowieka. W tym celu Izrael - świadek Bożego miłosierdzia - wzywa narody na drogę nawrócenia, wskazując im drogę Bożego prawa, Tory (Iz 55,5-7), której pierwszym wymogiem jest odrzucenie bałwochwalstwa i przyjęcie monoteistycznej wiary Izraela (Iz 43,9-10.12; 44,8-9): „Nie będziesz miał bogów cudzych przede Mną". W tym wezwaniu narodów do nawrócenia (קרא -qāāă: Iz 55,5.6-7) objawia się kolejna ważna cecha teologiczna Dawidowego świadectwa: odpowiedzialność.

${ }^{69}$ Wydaje się, że innego zdania jest K. B a 1 t z e r, Deutero-Isaiah, s. 471.

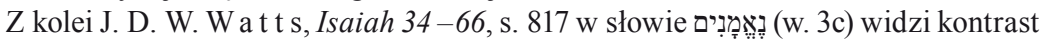
między wiecznym przymierzem Dawida i przymierzem Mojżesza, które - oparte na posłuszeństwie Torze - straciło na znaczeniu. Tak też uważa św. Cyryl z Aleksandrii, cytując w tym kontekście Hbr 8,7; zob. J.-P. M i g n e (red.), Patrologia cursus completus. Series Graeca, t. 70, kol. 1221-1225. 
Choć Izrael mógł żywić głęboką urazę za doznane krzywdy ze strony obcych narodów, to jednak zostaje przez Boga wezwany do dojrzałości w wierze, którą osiąga, wznosząc się niemal na poziom Bożej transcendencji, stając przy Jahwe nie tylko jako świadek Boskiego miłosierdzia (w. 7), ale również jako głos Jego mesjańskiej Mądrości, która nawołuje innych do nawrócenia (w. 6) i przekazuje

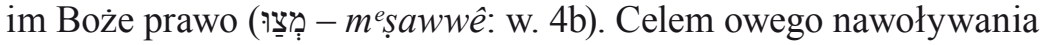
jest poszerzenie obszaru normatywnej świętości Tory na inne ludy, w czym wyraża się uniwersalizm tego przesłania.

Obraz Izraela jako mesjańskiej Mądrości Boga nie jest jedynie stylizacją językową. To obraz Izraela, który w kanonicznej Księdze Deuteroizajasza (Iz 40-55) rzeczywiście staje się sumieniem narodów. I tak jak niegdyś takim sumieniem była dla Izraela Arka

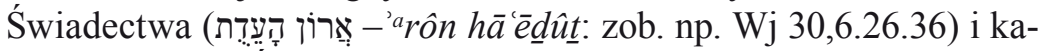

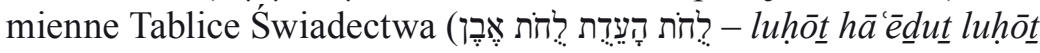
'eben: zob. np. Wj 31,18.32,15), tak teraz on, Boży świadek, pełni tę mesjańską rolę w stosunku do całego świata.

$$
* * *
$$

Iz 55,3-5 ukazuje wizję wiecznego przymierza, które odnowi dawną relację z Jahwe i wyznaczy nową podstawę narodowo-religijnej samoświadomości Izraela w okresie powygnaniowym. Izrael zostanie ustanowiony świadkiem i prawodawcą narodów. W przestawieniu tej teologicznej nowości Deuteroizajasz ucieka się do ciekawej stylizacji językowej i przedstawia Izrael jako mesjańską Mądrość stojącą pośród narodów i nawołującą do nawrócenia i przyjęcia Bożego prawa. Przyjęcie Bożego prawa jest bowiem warunkiem nawrócenia i otrzymania przebaczenia. W swym nawoływaniu Izrael, którego grzechy - „po odebraniu kary w dwójnasób” (Iz 40,2) - zostały odpuszczone, jest wiarygodnym świadkiem Bożego miłosierdzia. Czyż i on nie powinien teraz przebaczyć narodom, które go ciemiężyły?

ks. Arnold ZAWADZKI 
Słowa kluczowe: Dawidowego świadectwo, świadek, Dawid, wieczne przymierze, Deuteroizajasz, narody, mesjańska Mądrość

Keywords: Davidic testimony, witness, David, eternal covenant, Deutero-Isaiah, nations, Messianic Wisdom

\section{Israel as Messianic Wisdom in Isa 55:3-5 and Her Witness among the Nations. An Exegetical and Historical Study \\ Summary}

The article tries to describe the theology of David's testimony in Isaiah 55:3-5 in light of its historical background, to wit the last decade of the Babylonian exile, and in relation to the internal quandary of Judean Exiles. The study undertakes an inquiry into the question of whether the eternal covenant in Isaiah 55:3-5 is the continuation of the Sinaitic Covenant, or rather does its content go beyond the Mosaic Law, creating a totally new relationship of God with Israel. The study also draws attention to the existence of a redactional addition, which swifts the weight of the original message from a revanchist Judeo-centrism toward the irenic ethnic-centrism typical of the Book of Jonah. 